\title{
Dietary Phosphorus and Calcium Utilization in Growing Pigs: Requirements and Improvements
}

\author{
Marion Lautrou ${ }^{1,2 *}$, Agnès Narcy ${ }^{3}$, Jean-Yves Dourmad ${ }^{4}$, Candido Pomar $^{5}$, \\ Philippe Schmidely ${ }^{2}$ and Marie-Pierre Létourneau Montminy ${ }^{1}$
}

${ }^{1}$ Département des sciences animales, Université Laval, Quebec, QC, Canada, ${ }^{2}$ UMR Modélisation Systémique Appliquée aux Ruminants, INRA, AgroParisTech, Université Paris-Saclay, Paris, France, ${ }^{3}$ UMR Biologie des oiseaux et aviculture, INRA, Nouzilly, France, ${ }^{4}$ PEGASE, Agrocampus Ouest, INRA, Saint-Gilles, France, ${ }^{5}$ Agriculture et Agroalimentaire Canada,

Sherbrooke, QC, Canada

\section{OPEN ACCESS}

Edited by:

Luciano Hauschild,

São Paulo State University, Brazil

Reviewed by:

Thomas D. Crenshaw,

University of Wisconsin-Madison,

United States

Yang Zhi

Yangzhou University, China

*Correspondence:

Marion Lautrou

marion.lautrou.1@ulaval.ca

Specialty section:

This article was submitted to Animal Nutrition and Metabolism,

a section of the journal

Frontiers in Veterinary Science

Received: 01 July 2021 Accepted: 04 October 2021 Published: 24 November 2021

Citation:

Lautrou M, Narcy A, Dourmad J-Y,

Pomar C, Schmidely $P$ and Létourneau Montminy M-P (2021) Dietary Phosphorus and Calcium Utilization in Growing Pigs: Requirements and Improvements. Front. Vet. Sci. 8:734365 doi: 10.3389/fvets.2021.734365
The sustainability of animal production relies on the judicious use of phosphorus (P). Phosphate, the mined source of agricultural phosphorus supplements, is a non-renewable resource, but phosphorus is essential for animal growth, health, and well-being. $\mathrm{P}$ must be provided by efficient and sustainable means that minimize the phosphorus footprint of livestock production by developing precise assessment of the bioavailability of dietary $\mathrm{P}$ using robust models. About $60 \%$ of the phosphorus in an animal's body occurs in bone at a fixed ratio with calcium $(\mathrm{Ca})$ and the rest is found in muscle. The $\mathrm{P}$ and $\mathrm{Ca}$ requirements must be estimated together; they cannot be dissociated. While precise assessment of $\mathrm{P}$ and $\mathrm{Ca}$ requirements is important for animal well-being, it can also help to mitigate the environmental effects of pig farming. These strategies refer to multicriteria approaches of modeling, efficient use of the new generations of phytase, depletion and repletion strategies to prime the animal to be more efficient, and finally combining these strategies into a precision feeding model that provides daily tailored diets for individuals. The industry will need to use strategies such as these to ensure a sustainable plant-animal-soil system and an efficient $\mathrm{P}$ cycle.

\section{Keywords: phosphorus, calcium, mitigation, requirements, environment, swine}

\section{INTRODUCTION}

Phosphorus (P) is an essential element for all living beings, as it is a key component of nucleic acids and energy transfer molecules (adenosine triphosphate, creatine phosphate) and a major mineral component of bone (1). The element $\mathrm{P}$ is found in animals as orthophosphates. This is the circulating form of P. Adequate amounts must be provided in livestock diets to ensure animal growth and health. To date, producers have used inorganic phosphate, a limited and non-renewable resource that will be depleted within 100-200 years at current rates of extraction (2). As a commodity mineral, its price is volatile (3). Of greater concern is that P is not absorbed completely from any diet, and in the case of monogastric livestock farming, phosphorus-laden run-off can pollute and cause eutrophication of waterways, which can lead to growth of toxic nitrogen-fixing algae or cyanobacteria (4). This compromises the sustainability of pig farming, which has become highly concentrated in certain regions of several pork-producing countries. In swine production, to avoid an excess of $\mathrm{P}$, the cost of transporting P-rich manure for use as crop field fertilizer can be high and the cost of treating it can be prohibitive; rational and efficient use of $\mathrm{P}$ is therefore essential. 
Calcium (Ca) is the most abundant mineral in the body $(1,5)$ and is indispensable for bone mineralization, muscle contraction, and nerve impulse propagation. It is not an expensive element in livestock feed, it is abundant, and it does not represent a threat to the environment. However, as absorption and utilization of $\mathrm{P}$ in growing pigs is related to that of $\mathrm{Ca}, \mathrm{P}$ and $\mathrm{Ca}$ requirements must be studied together. Insoluble and indigestible $\mathrm{Ca}-\mathrm{P}$ complexes can form in the intestines $(6,7)$. Ca and $\mathrm{P}$ deposits in bone are co-dependent. If discharges of phosphorus are to be minimal and its efficiency of utilization must be maximized, its supply must be matched as closely as possible to the requirements of the animals. To achieve this, the actual usable P content of feedstuffs and the animal physiological requirement both must be estimated accurately and precisely. Both global and factorial methods have been used to estimate the $\mathrm{Ca}$ and $\mathrm{P}$ requirement.

$\mathrm{P}$ and $\mathrm{Ca}$ requirements can be estimated to maximize growth performance, keep $\mathrm{P}$ rejection minimal and/or maximize bone mineralization. Novel approaches in development aim to improve the digestive and/or metabolic utilization of $\mathrm{P}$, thereby decreasing $\mathrm{P}$ excretion. The best-known example is the use of phytases, which facilitate the digestion of plant $\mathrm{P}$ as phytic acid, the phosphoric ester of inositol, a compound found in many plants and poorly absorbable by pigs. The new generation of phytases makes this strategy even more attractive. The depletionrepletion, a strategy less well known, consists of reducing $\mathrm{P}$ and $\mathrm{Ca}$ input below the animal's requirements over some period of growth and then increasing the supply as needed (8). This strategy can increase the animal's $\mathrm{P}$ digestive efficiency and metabolic utilization in growing pigs; thus it overall decreases in $\mathrm{P}$ intake and excretion while maintaining growth and bone mineralization $(9,10)$. Finally, a mechanistic model approach predicts bone ash and then $\mathrm{P}$ and $\mathrm{Ca}$ requirement $(11,12)$ and does not estimate the $\mathrm{P}$ and $\mathrm{Ca}$ requirement for bone directly from protein. This is an interesting multicriteria approach to mitigate $\mathrm{P}$ impact that will be essential for $\mathrm{P}$ precision feeding (13). The objective of this paper is to review the latest $\mathrm{P}$ and $\mathrm{Ca}$ assessment of bioavailability methods for evaluating the nutritional values of feed ingredients for pigs and estimating precisely $\mathrm{P}$ requirements, as well as, describing innovations and promising strategies to decrease the $\mathrm{P}$ excretions by growing pigs.

\section{PRECISELY ASSESS BIOAVAILABILITY AND EVALUATING THE NUTRITIONAL VALUES OF FEED INGREDIENTS}

\subsection{Dietary Forms of Phosphorus and Calcium}

\subsubsection{Plant Phosphorus and Calcium}

Phytic acid is synthesized in plants by phosphorylating inositol in any or all possible positions. It can thus bear 6 phosphate groups $\left(\mathrm{IP}_{6}\right)$ as shown in Figure 1, or a smaller number $\left(\mathrm{IP}_{5^{-}}\right.$ $\left.\mathrm{IP}_{1}\right)$. The main form found in feed ingredients of plant origin is $\mathrm{IP}_{6}(15,16)$. Phytic acid plays a key role in plant metabolism by constituting a reserve of $\mathrm{P}$ and chelating other minerals, whereas inositol is used in cell wall formation (17). Phytic acid is present in all plant-based ingredients (18), in which it accounts for 50$80 \%$ of the P content $(19,20)$ and is found almost entirely in the form of salts called phytates, primarily with $\mathrm{Ca}, \mathrm{Fe}, \mathrm{Zn}, \mathrm{Mg}, \mathrm{K}$, and $\mathrm{Mn}$. Phytates are solubilized at gastric $\mathrm{pH}$, whereas the higher $\mathrm{pH}$ of the small intestine is conducive to their re-formation or de novo complexation thus decreasing the absorption of minerals and trace elements $(21,22)$. In vitro, phytic acid forms its most stable salts with $\mathrm{Cu}, \mathrm{Zn}, \mathrm{Ni}, \mathrm{Co}, \mathrm{Mn}, \mathrm{Fe}$, and then $\mathrm{Ca}$ $(23,24)$. Ca rarely makes up more than $1 \%$ of plant dry matter (20) and its absorption is decreased by phytate formation, but this can be countered somewhat by using phytases (see section 4.2), which break down phytates that are in solution (25-27). The cation-binding ability of phytic acid declines as phosphate groups are removed (21). Phytates form insoluble complexes also with proteins, amino acids, and starch and thereby decrease the digestibility in the small intestine and utilization of these nutrients (18).

\subsubsection{Mineral Phosphorus and Calcium}

$\mathrm{P}$ is usually added to pig diets as dicalcium phosphate, which represents $60 \%$ of the feed phosphates used in the European Union; monocalcium and monodicalcium phosphates are also used (28). Magnesium, calcium-magnesium, ammonium, and sodium phosphates are also available for use in livestock feed (2830). To minimize excreted phosphate, which becomes pollution, the most digestible phosphates are preferred, although price also is considered. The first and foremost criterion is to meet narrow technical specifications in terms of composition and physicochemical stability. Phosphates can be classified according to their solubility in $2 \%$ citric acid solution. This test does not indicate real digestibility but makes it possible to rank different products (29). A feed-grade phosphate must be at least $95 \%$ soluble in $2 \%$ citric acid and in alkaline ammonium citrate (28, 31 ). For monocalcium phosphates, the solubility in water must be greater than $80 \%$, and for monodicalcium phosphate, greater than $50 \%$ (28). Monocalcium phosphate is more digestible than monodicalcium phosphate, which is more digestible than dicalcium phosphate $(28,29)$. Dicalcium phosphate dihydrate is more digestible than the anhydrous form. The final criterion for judging the quality of a feed-grade phosphate is its level of undesirable substances such as arsenic, cadmium, lead, fluorine, or mercury, and dioxins $(28,29)$.

The inorganic Ca supplements most used in pig farming are calcium phosphates (32) and carbonates supplied in the form of limestone, a mineral that contains calcium carbonate and dolomite and which varies in Ca content (35-38\% Ca; (19)). The bioavailability of the $\mathrm{Ca}$ in these sources is in the 90$100 \%$ range of calcium carbonate $\left(\mathrm{CaCO}_{3}\right)$ used as reference $(19,20,30)$. Unlike in poultry, carbonate particle size appears to have no significant effect on apparent or standardized $\mathrm{Ca}$ digestibility in growing pigs, based on tests with animals in the $10-20 \mathrm{~kg}$ live weight range $(33,34)$. Calcified red algae has been studied due to its solubility at gastric $\mathrm{pH}$. It is $32 \%$ more soluble than calcareous $\mathrm{Ca}$ at $\mathrm{pH} 6.7$ and $34 \%$ more soluble at pH 3.0 (35). Limestone is $100 \%$ calcite, whereas CeltiCal (Celtic Sea Minerals) is $65 \%$ calcite, $23 \%$ aragonite, and $12 \%$ valterite (polymorphs of calcite). The greater solubility does not make 

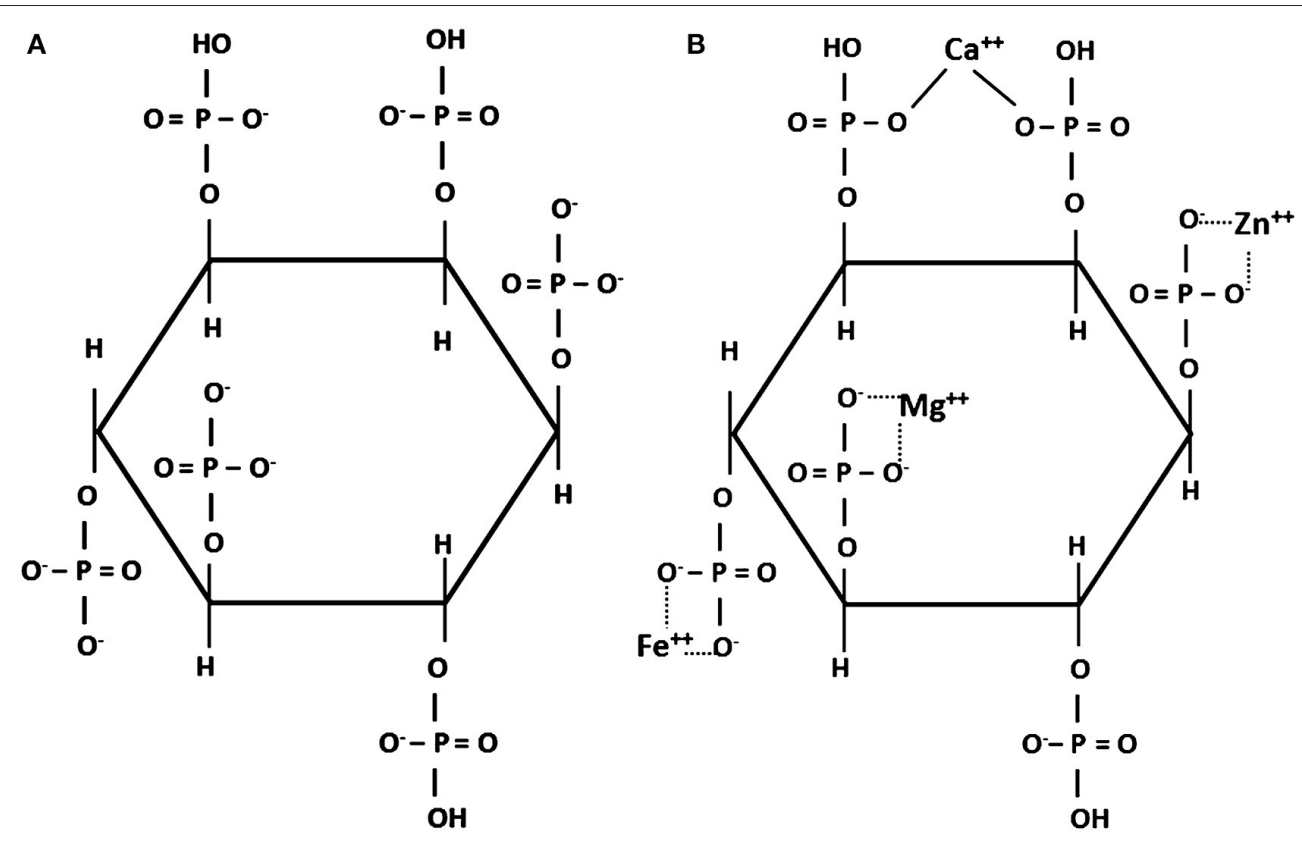

FIGURE 1 | (A) Structure of phytic acid at neutral pH (14); (B) phytate chelate with different cations. (14).

the Celtic Sea product more digestible than calcium carbonate. Its digestibility in pigs is at best equivalent to that of calcium carbonate [apparent total tract digestibility [ATTD] Ca of $46.7 \%$ and $51.2 \%$ for calcium carbonate and CeltiCal, respectively (36), $64 \%$ for both sources (37), and may be lower: $46.9 \%$ of ATTD $\mathrm{Ca}$ and $30.5 \%$ for calcium carbonate and CeltiCal (38)]. Marine $\mathrm{Ca}$ is absorbed poorly in the upper parts of the gut (38); the higher concentration of dissolved cations moreover makes it precipitate more with phosphate or phytic acids, decreasing $\mathrm{P}$ digestibility, bone mineralization, and animal growth (35, 36). A highly soluble $\mathrm{Ca}$ to $\mathrm{P}$ ratio makes precipitation more likely. Nevertheless, adding marine $\mathrm{Ca}$ in smaller amounts and using phytase allows proper balancing of the soluble $\mathrm{Ca}: \mathrm{P}$ ratio and growth performance equivalent to the control group, and quantitatively superior bone mineralization, at least in broiler chicken studies (35). These results show, above all, that $\mathrm{Ca}$ and $\mathrm{P}$ interact strongly in the digestive system, and how much further study, especially of the soluble Ca:P ratio, is needed to optimize their utilization.

\subsubsection{Phosphorus and Calcium of Animal Origin}

In addition to inorganic phosphates, meat and bone meal from the rendering industry is also used as a source of $\mathrm{P}$ and Ca. Except in Europe, where it is prohibited in livestock feed other than for fish, these by-products are commonly included in poultry diets. Meat and bone meal can be made up of bones and soft tissues but not blood, hair, hoof, horn, skin/leather, stomach and ruminal contents, or excrement. Most meat and bone meal in North America is a mixture of cattle, pig, and poultry by-products (39). It must contain at least $4.0 \%$ of $\mathrm{P}$, and the $\mathrm{Ca}: \mathrm{P}$ ratio must not exceed 2.2 [AAFCO 2011, cited in Sulabo and Stein (40)]. Meat and bone meal is a source of highly available $\mathrm{Ca}$ and P $(41,42)$ but has unpredictable quality and $\mathrm{Ca}: \mathrm{P}$ ratios, due to differences in raw materials and processes (39). Depending on the source, the $\mathrm{P}$ and Ca contents may vary $2-4$ times as much as the protein content, the coefficients of variance being, respectively, 20, 22, and $6.2 \%(40)$. A negative correlation exists between protein concentration and $\mathrm{P}$ and $\mathrm{Ca}$ concentration, due to variations in the proportions of soft tissue and bone (40). The most important sources of variation in the composition of meat and bone meal are therefore the origin of the by-products used and the ratio of soft tissue to bone.

When meat and bone meal is fed to pigs, it provides much of the $\mathrm{Ca}$ and $\mathrm{P}$ in the diet. It is therefore necessary to have a supplier that uses controlled processes and can guarantee $\mathrm{Ca}$ and $\mathrm{P}$ content. The standardized digestibility of $\mathrm{P}$ in meat and bone meal ranges from 55 to $84 \%$ and averages $70 \%(20,40)$, falling between the values for inorganic $\mathrm{P}$ and materials of plant origin. Standardized Ca digestibility in meat and bone meal is estimated at $77 \%$ but can be $82 \%$ for poultry meal (43). The apparent $\mathrm{Ca}$ digestibility ranges from 55 to $84 \%$ (40). The digestibility of $\mathrm{P}$ and $\mathrm{Ca}$ in meat and bone meal does vary somewhat, due mostly to the $\mathrm{P}$ concentration: the higher the $\mathrm{P}$ concentration, the lower the $\mathrm{Ca}$ and $\mathrm{P}$ digestibility. Since the $\mathrm{P}$ concentration depends mainly on the proportion of bone in the meal, it may be presumed that the higher the bone-to-meat ratio, the lower the $\mathrm{Ca}$ and $\mathrm{P}$ digestibility. The apparent digestibility of $\mathrm{P}$ in bone meal is in fact about 68 vs. $80 \%$ in meat-and-bone meal and $85 \%$ in meat meal (44). Hydroxyapatite, therefore, seems to be a less digestible form of $\mathrm{P}$ and $\mathrm{Ca}$. This has been validated for $\mathrm{P}$ by comparing diets containing different forms of bone meal. The pre-cecal digestibility of $\mathrm{P}$ in chickens is lower when it is still in the form 
of hydroxyapatite than when it has been previously dissolved (45). Although its composition may vary widely, meat and bone meal offers the possibility of recycling, providing sufficient $\mathrm{P}$ to livestock without inorganic $\mathrm{P}$ from non-renewable sources. At least one study suggests that heat and pressure treatment of bone meal and removal of gelatin may improve P digestibility (45).

\subsection{Precisely Estimates of Dietary Phosphorus and Calcium Values of Feedstuffs}

\subsubsection{Total Analyzable Value}

Total dietary $\mathrm{Ca}$ and $\mathrm{P}$ content in feed ingredients are routinely measured by chemical analysis. However, these numbers do not indicate what portion the animals digest or retain or how much will be excreted. Although this method has its drawbacks, it is still the preferred method for Ca, mainly because of the lack of knowledge on Ca bioavailability. Recent work underway is expected to provide a more accurate Ca bioavailability assessment method with standardized digestibility measurements (46). The $\mathrm{P}$ system is more precise with different expression modes, which will be described in the following sections.

\subsubsection{Relative Bioavailability}

Bioavailability, also called availability, was added in the ninth edition of NRC (47). Availability is an indicator of the use of a nutrient based on a predefined criterion, for example, in the case of $\mathrm{P}$ and $\mathrm{Ca}$, bone mineralization measured in terms of mineral (ash) content or a biomechanical property such as breaking strength $(48,49)$. The value is obtained by comparison with a reference that is considered $100 \%$ bioavailable, usually monocalcium phosphate. The relative bioavailability of a nutrient in an ingredient is generally expressed as the slope ratio, which is obtained from linear regressions of the criterion vs. nutrient ingested (48). The main disadvantage of this method is that it is not standardized and thus the bone and parameter measured (e.g., ash content and break strength) may differ between studies, so studies are not comparable (46).

\subsubsection{Digestibility}

The digestibility concept was first used to assess $\mathrm{P}$ content of feedstuffs as ATTD in the Netherlands (50) and then in France (19). In 2012, the National Research Council (NRC) proposed another method, like the one used for amino acid and that should be more precise, the standardized total tract digestibility (STTD). Digestibility refers to the quantity of nutrient that is not found in the feces and therefore must have been digested, or, at least, has disappeared from the digestive tract, a definition that must be nuanced according to whether endogenous losses are considered. Unlike other nutrients, the digestibility of $\mathrm{P}$ (and of $\mathrm{Ca}$ to a lesser extent) is estimated over the entire digestive tract as fecal digestibility. Two reasonable assumptions justify this: (1) P and $\mathrm{Ca}$ are absorbed in the cecum and the colon, respectively (51). These play a homeostatic role in maintaining serum $\mathrm{P}$ and $\mathrm{Ca}$ under conditions of low intake, and (2) for $\mathrm{P}$ and $\mathrm{Ca}$ in most dietary supplies, there are no difference between fecal and ileal digestibility for true and apparent $\mathrm{P}$ digestibility $(52,53)$, or apparent and standardized Ca digestibility (38) and therefore no interest in estimating ileal digestibility, which is much more difficult and expensive than measuring fecal digestibility (20).

Apparent total tract digestibility (ATTD) of a nutrient in a feed is the difference between the total intake of the nutrient in question and the amount found in the feces $(54,55)$ :

$$
\begin{aligned}
\operatorname{ATTD}_{\text {Ca or } P}(\%) & =\left[\left(\text { Ca or } P_{\text {intake }}-\text { Ca or } P_{\text {feces }}\right) / \text { Ca or } P_{\text {intake }}\right] \\
& \times 100
\end{aligned}
$$

The methods most used to determine apparent digestibility are total feces collection or partial collection in conjunction with an indigestible marker. Apparent P digestibility is still used widely but has the disadvantage of not being additive in feeds composed of several ingredients $(55,56)$.

STTD considers basal endogenous losses, which represent the minimal loss of a nutrient, independent of feed composition but influenced by dry matter intake (49, 54). These losses were first estimated by regression with extrapolation to zero ingestion of the studied mineral (57). They are now measured by analyzing feces of animals fed a diet free of $\mathrm{P}$ or $\mathrm{Ca}(34,37$, 58-60). Critics of this method point out that Ca metabolism is well known to be regulated through absorption and thus reabsorption of endogenous losses, leading to underestimation of basal endogenous losses (61). Likewise, a P imbalance due to a Pfree but Ca-containing feed would probably affect endogenous $\mathrm{P}$ losses (62). Further trials are needed to determine whether endogenous $\mathrm{P}$ losses should be measured with a P-free and $\mathrm{Ca}$-free diet, or if it is better to measure $\mathrm{P}$ losses with some $\mathrm{Ca}$ to minimize interference by regulation. Basal endogenous losses of $\mathrm{P}$ and Ca fall, respectively, into the ranges of 139-252 $\mathrm{mg}$ and $123-670 \mathrm{mg} / \mathrm{kg}$ of dry matter intake (DMI) $(37,38,63,64)$. Basal endogenous $\mathrm{P}$ losses in pigs have been estimated at $190 \mathrm{mg} / \mathrm{kg}$ of DMI by (20) and $6 \mathrm{mg} / \mathrm{kg}$ of live bodyweight (BW) by Bikker and Blok (65). Standardized digestibility can then be calculated using the following equation (55):

$$
\begin{aligned}
\operatorname{STTD}_{\text {Ca or } P}(\%) & =\left[\left(\text { Ca or } P_{\text {intake }}-\left(\text { Ca or } P_{\text {feces }}\right.\right.\right. \\
& \left.- \text { Basal endogenous losses })) / \text { Ca or } P_{\text {intake }}\right] \\
& \times 100
\end{aligned}
$$

Standardized digestibility values are considered additive in feeds composed of several raw materials $(20,46)$. According to this equation and the use of a constant basal P loss of $190 \mathrm{mg} / \mathrm{kg}$ of DMI, it is simple to convert values of ATTD digestibility values into STTD values.

True digestibility accounts for total endogenous losses, which include basal and specific endogenous losses. The latter represents the losses above basal endogenous ones, due to specific characteristics of the feed, such as the level of anti-nutritional factors and fiber content (54). No method of direct measurement of true digestibility exists, except the use of radioisotopes that are now banned in many countries. It is therefore determined by regression, using apparent digestibility and ingested quantity of the nutrient $(46,49)$ :

Ca or $P_{\text {absorbed }}=\left(T T T D \times\right.$ Ca or $\left.P_{\text {intake }}\right)-$ Total endogenous losses 
The negative intercept corresponds to total endogenous loss, while the slope of the regression represents true digestibility. Critics of this method point out that for $\mathrm{P}$ and $\mathrm{Ca}$, estimates are highly variable, dependent on individuals, often intercept is not different from $0(53,66,67)$ and influenced by the amount ingested, in violation of the basic assumption of the regression method $(66,67)$.

Although several studies about $\mathrm{Ca}$ digestibility have been completed $(34,37,40,52,59,66,68)$, the $\mathrm{Ca}$ requirement continues to be generally expressed as a total requirement $(20,46)$ due to the lack of data on digestibility in specific feed ingredients. To overcome the non-additivity of apparent digestibility in a mixed feed, most recent studies have focused on standardized digestibility (59). However, basal endogenous Ca losses measured so far are highly variable and appear to depend on feed composition (59). In addition, components such as fiber may have a direct and proportionate positive effect on standardized Ca digestibility (59), as shown in rat studies (69). These last considerations show the interest in evaluating the $\mathrm{Ca}$ digestibility of raw materials under the specific conditions in which they will be used, as recommended in chicken for $\mathrm{P}(70)$.

\subsubsection{Mechanistic Modeling and Meta-Analysis Approach}

All the methods described earlier give a unique $\mathrm{P}$ and $\mathrm{Ca}$ value for each feedstuff regardless of the interactions with other components of the diet. With the objective of precisely estimate the digestibility of dietary $\mathrm{P}$ in a complete diet, two approaches have been used by Létourneau-Montminy et al. (71, 72) based on available literature. First, a mechanistic research mathematical model that simulates the fate of dietary $\mathrm{P}$ forms, phytate $\mathrm{P}$ (PP) and non-phytate $\mathrm{P}$ (NPP) from plant, mineral and animal origin, in the gastro-intestinal-tract was developed and evaluated by Létourneau-Montminy et al. (71). The proposed model integrates and predicts the impact of the most relevant physiological processes involved in $\mathrm{P}$ digestion and absorption, including $\mathrm{P}$ dietary forms, the presence of exogenous phytase, and the dietary concentration of $\mathrm{Ca}$. It also predicts the impact of transit time and $\mathrm{pH}$ of the different dietary sections. The output is the standardized $\mathrm{P}$ and $\mathrm{Ca}$ absorbed. It can be used as a prospective tool to study $\mathrm{P}$ digestibility for different feedstuffs and feeding strategies, as well as the effect of specific digestive processes on $\mathrm{P}$ digestive utilization. Second, given the large number of publications on $\mathrm{P}$ digestibility in pigs, meta-analysis, a statistical method relevant for summarizing and quantifying knowledge acquired through previously published research (73, 74), was chosen to predict $\mathrm{P}$ digestibility considering dietary $\mathrm{P}$ forms, $\mathrm{Ca}$, and exogenous phytases. Dietary forms are PP and NPP from plant, mineral, and animal (72). This study provided a generic response of ATTD P $(\mathrm{g} / \mathrm{kg})$ to variation of PP, NPP, and phytase. Results showed a linear relationship between NPP and digestible P. Both NPP from mineral and animal feedstuffs and NPP from plant are highly digestible (78 and $73 \%$, respectively). A digestibility coefficient of $21 \%$ was also found for PP showed that part of the PP is available for absorption without any exogenous phytase supply (75-77). Then microbial phytase improved digestible $\mathrm{P}$ given hydrolysis was simulated with a classic enzyme equation, the Michaelis-Menten. Its response depends on PP quantity, its substrate. The addition of 500 FTU of microbial phytase per $\mathrm{kg}$ of feed to a diet with 2 $\mathrm{g}$ of $\mathrm{PP} / \mathrm{kg}$, increased the amount of digestible P by $0.60 \mathrm{~g} / \mathrm{kg}$. With $3 \mathrm{~g}$ of $\mathrm{PP} / \mathrm{kg}$, the amount of digestible $\mathrm{P}$ increased by $0.67 \mathrm{~g} / \mathrm{kg}$. It is worthy to note that the amount of PP varies little in swine ingredients. Finally, dietary $\mathrm{Ca}$ linearly decreases digestible $\mathrm{P}$ independently of phytase supply as previously shown when testing different concentrations of dietary Ca crossed with different levels of phytase $(78,79)$. This simple method allows a prediction of true $\mathrm{P}$ digestibility based on chemical analysis of the diet in total P, PP, Ca, and microbial phytase, while NPP is the difference between total P and PP as used in broilers (80).

\section{PRECISELY ASSESS PHOSPHORUS AND CALCIUM REQUIREMENTS}

According to the FAO and WHO (81), a nutrient requirement is defined as the intake level that will meet specified criteria of adequacy without risking deficit or excess. These criteria include an array of biological effects associated with the nutrient. In livestock production, a requirement is defined as the quantity necessary to maximize a production factor such as body growth or bone mineralization. In practice, growth alone is often a poor indicator of mineral status. Tissue analyses should always accompany growth and feed intake data when evaluating mineral adequacy (82). Bone mineralization has long been the standard, but environmental issues have led several countries to review this, giving rise to the notion of growth performance (20). Ca and $\mathrm{P}$ requirements may be defined as facilitating growth according to genetic potential while ensuring optimal bone mineralization and keeping environmental risks minimal. In other words, a multicriteria approach to setting nutrient requirements is needed. To respond to these different objectives, global and factorial approaches, and increasingly mechanistic models simultaneously consider the most important variables, including genetics, live weight, and sex.

\subsection{Global Approach}

This method consists of measuring different performance criteria (growth rate, feed conversion ratio, etc.) in herds that have been fed with increasing levels of the tested nutrient. If all the criteria are not satisfied simultaneously, the proper intake is then considered to be the one that optimizes the most important criterion (83). At this time, the digestibility of nutrients was not considered. This approach presents two main disadvantages. The first one is that it is difficult to compare the estimation of nutrient requirements by this approach with the availability or digestibility of the raw material. The second is that, like nutrient availability, the approach does not consider the portions of $\mathrm{P}$ and Ca effectively used and does not allow differentiation between the portions released in feces and urine. Global approaches were replaced by factorial approaches in the 1990s.

\subsection{Factorial Approaches}

A more advanced method is the factorial approach, which consists of quantification and the addition of the requirements 
TABLE 1 | Estimates of $P$ and Ca requirements for growing pigs according to different models.

\begin{tabular}{|c|c|c|c|c|c|c|c|c|c|c|c|c|c|c|c|c|}
\hline Bodyweight & \multicolumn{4}{|c|}{$30 \mathrm{~kg}$} & \multicolumn{4}{|c|}{$50 \mathrm{~kg}$} & \multicolumn{4}{|c|}{$70 \mathrm{~kg}$} & \multicolumn{4}{|c|}{100 kg } \\
\hline ADG & \multicolumn{4}{|c|}{$0.96 \mathrm{~kg}$} & \multicolumn{4}{|c|}{$1.11 \mathrm{~kg}$} & \multicolumn{4}{|c|}{$1.17 \mathrm{~kg}$} & \multicolumn{4}{|c|}{$1.12 \mathrm{~kg}$} \\
\hline Feed intake & \multicolumn{4}{|c|}{$1.36 \mathrm{~kg}$} & \multicolumn{4}{|c|}{$2.14 \mathrm{~kg}$} & \multicolumn{4}{|c|}{$2.71 \mathrm{~kg}$} & \multicolumn{4}{|c|}{$3.22 \mathrm{~kg}$} \\
\hline \multirow[t]{2}{*}{ Body protein } & \multicolumn{4}{|c|}{$4.68 \mathrm{~kg}$} & \multicolumn{4}{|c|}{$7.08 \mathrm{~kg}$} & \multicolumn{4}{|c|}{$11.09 \mathrm{~kg}$} & \multicolumn{4}{|c|}{$15.03 \mathrm{~kg}$} \\
\hline & CVB $^{a}$ & $\mathrm{NRC}^{b}$ & INRAe $^{c}$ & Lautrou $^{d}$ & CVB $^{a}$ & $\mathrm{NRC}^{b}$ & INRAe $^{c}$ & Lautrou $^{d}$ & CVB $^{a}$ & $\mathrm{NRC}^{b}$ & INRAe $^{c}$ & Lautrou $^{d}$ & CVB $^{a}$ & $\mathrm{NRC}^{b}$ & INRAe $^{c}$ & Lautrou $^{d}$ \\
\hline STTD P (g/kg) & 3.77 & 4.2 & - & 4.07 & 2.83 & 3.07 & - & 2.85 & 2.39 & 2.45 & - & 2.38 & 2.01 & 1.83 & - & 2.12 \\
\hline ATTD P (g/kg) & - & - & 4.0 & 3.9 & - & - & 2.98 & 2.68 & - & - & 2.5 & 2.21 & - & - & 2.1 & 1.95 \\
\hline Total Ca (g/kg) & 9.96 & 9.03 & 11.61 & 8.16 & 7.53 & 6.6 & 8.65 & 5.9 & 6.38 & 5.27 & 7.26 & 5.2 & 5.4 & 3.93 & 6.09 & 5.06 \\
\hline Total Ca:STTD P & 2.64 & 2.15 & - & 2.00 & 2.66 & 2.15 & - & 2.07 & 2.67 & 2.15 & - & 2.18 & 2.69 & 2.15 & - & 2.39 \\
\hline Total Ca:ATTD P & - & - & 2.90 & 2.09 & - & - & 2.90 & 2.20 & - & - & 2.90 & 2.35 & - & - & 2.90 & 2.59 \\
\hline
\end{tabular}

${ }^{a}$ Estimated according to Bikker and Blok (65).

${ }^{b}$ Estimated according to NRC (20).

${ }^{c}$ Estimated according to Jondreville and Dourmad (84).

${ }^{d}$ estimated according to Lautrou et al. (12).

for each physiological function (e.g., for maintenance and growth). With the emergence of this method came the consideration of the intestinal absorption of minerals. Several factorial methods estimating $\mathrm{P}$ and $\mathrm{Ca}$ requirements had been proposed such as Jondreville and Dourmad (84), NRC (20), and Bikker and Blok (65). The first of these methods is based partly on studies conducted years ago in France $(83,85)$ and the Netherlands (86) and is applied widely in France and Europe. The second one is popular in North America. The third one is in fact an update of the Jongbloed et al. (86) method based on data published since then. The $P$ requirements estimated by these methods are presented in Table 1.

In Jondreville and Dourmad (84)'s model, estimation of $\mathrm{P}$ and $\mathrm{Ca}$ requirements aims for a bone mineralization of $100 \%$. The maintenance requirement corresponds to obligatory urinary losses, because the $\mathrm{P}$ requirements are expressed on an ATTD basis, and endogenous fecal losses are already considered. The maintenance $\mathrm{P}$ requirements are estimated at $10 \mathrm{mg} / \mathrm{kg}$ of BW (85). The requirement for growth is assessed based on the average daily gain. Finally, the total Ca requirement is estimated according to a fix ratio of 2.9 with the ATTD P requirement.

The NRC (20) considers that $\mathrm{P}$ and $\mathrm{N}$ retention are highly correlated, and that this correlation is affected little by animal genetics or sex. According to their model, maximal $\mathrm{P}$ retention in growing pigs is dependent on body protein. Endogenous basal losses in the gastrointestinal tract are estimated at $190 \mathrm{mg} / \mathrm{kg}$ of DMI, to express the P requirements in STTD, and minimal urinary loss at $7 \mathrm{mg} / \mathrm{kg}$ of BW. Finally, growth performance is maximized by considering the standardized digestible $\mathrm{P}$ requirement to be $85 \%$ of the level that maximizes body $\mathrm{P}$ retention. The total $\mathrm{Ca}$ requirement is set at 2.15 times the standardized $\mathrm{P}$ requirement.

In Bikker and Blok (65), Ca and $\mathrm{P}$ requirements are estimated independently and aim for a bone mineralization of $100 \%$. The requirement is the sum of the $\mathrm{Ca}$ or $\mathrm{P}$ retention and the maintenance requirement. An allometric relationship links body $\mathrm{Ca}$ and $\mathrm{P}$ retention to animal empty body weight gain. The maintenance requirement includes the obligatory urinary loss

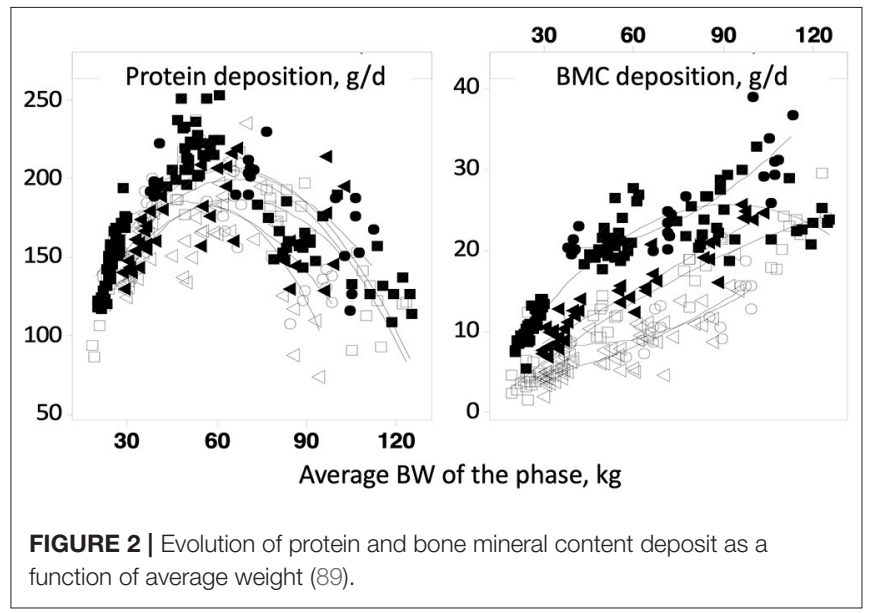

and the minimal endogenous loss. Basal fecal endogenous losses of $\mathrm{P}$ and $\mathrm{Ca}$ are set at $6 \mathrm{mg}$ and $8 \mathrm{mg} / \mathrm{kg}$ of BW, respectively, and obligatory urinary losses are estimated to be $1 \mathrm{mg}$ and $2 \mathrm{mg} / \mathrm{kg}$ of BW. These unavoidable losses are low under conditions of low $\mathrm{P}$ or Ca supply, and become greater as the supply increases. The utilization efficiency of the absorbed $\mathrm{P}$ and $\mathrm{Ca}$ is therefore set at $98 \%$. The $\mathrm{Ca}$ and $\mathrm{P}$ requirements are first estimated as standardized before applying a digestibility coefficient of $58 \%$ to the $\mathrm{Ca}$ requirement for expression as total $\mathrm{Ca}$. In this model, as in Sauveur and Perez (83) Ca requirement is estimated according to a factorial approach based on digestible $\mathrm{Ca}$ and expressed on a total basis assuming $45-50 \% \mathrm{Ca}$ digestibility. This permits adaptation of the Ca:digestible $\mathrm{P}$ requirement according to animal weight and performance. The same approach was recently used for sows by Gauthier et al. (87) and Gaillard et al. (88).

In all these models, ash deposition strongly correlates with soft tissue gain. However, recent feed trials have shown that this is not the case in growing pigs (Figure 2; 89). Protein deposition increases linearly up to a body weight of about $60 \mathrm{~kg}$, then decreases while bone mineral content deposition increases until the pigs reach slaughter weight $(120 \mathrm{~kg})$. These two variables 
are, therefore, measurements of different physiological processes. In the Jondreville and Dourmad (84) and NRC (20) models, the $\mathrm{Ca}$ requirement and the digestible $\mathrm{P}$ requirement form a fixed ratio throughout the life of the pig. However, as seen previously, bone growth and soft tissue growth are dissociated, which logically results in a Ca:P requirement ratio that is not the same throughout the life of the animal.

\section{STRATEGIES TO REDUCE PHOSPHORUS EXCRETION}

\subsection{Improved Mechanistic Models to Assess Phosphorus and Calcium Requirements}

The factorial approach can be integrated in a mechanistic model. The mechanistic models aim to represent the mechanisms of a system. In fact, they connect the underlying mechanisms that control operation of a system. It is, therefore, a matter to meet the conventional notion of requirements (homeorhesis, longterm response) with the response of the animals to inputs [homeostasis, short time scales, (90)]. In a more recent model (11), because of a lack of data, the potential $\mathrm{Ca}$ and $\mathrm{P}$ depositions were driven by potential protein deposition. But as seen previously, the protein and ash bone depositions are not correlated (89). Consequently, the assessment of $\mathrm{Ca}$ and $\mathrm{P}$ requirements must consider the fact that changes in skeletal tissue are not directly proportional to lean growth. This is clear when looking at the capacity of $\mathrm{P}$ - and Ca-depleted pigs to rapidly replace bone mass through compensatory bone mineralization (see section 4.3). This model has been revised (12) to rectify the no dependency of bone mineral deposition on protein gain by establishing a potential for $\mathrm{Ca}$ deposition independent of soft tissue gain, thus allowing $\mathrm{P}$ and $\mathrm{Ca}$ requirements for soft tissue growth and bone growth to be predicted independently (Figure 3).

This new model estimates apparent digestible $\mathrm{Ca}$ and $\mathrm{P}$ requirements, which can be converted to STTD or total requirements. The only input required is the initial body weight, from which body protein, lipid, water, and ash (soft tissue and bone) are estimated. Soft tissue growth is currently estimated by applying the principles of van Milgen et al. (91), although other models such as NRC (20) or even user-specific equations tailored to animal growth in a specific setting may be adequate. Estimated protein and lipid gains can be used to assess $\mathrm{P}$ and Ca retention in soft tissues (92). In parallel, the Ca requirement for bone is estimated with the bone Ca potential deposition curve presented by the same authors (12). The deposition of $\mathrm{P}$ in bone is estimated at a fixed ratio of 2.16 to Ca deposition. The maintenance requirements, equivalent to the obligatory urinary losses, are set at $0.5 \mathrm{mg}$ for $\mathrm{P}$ and $2 \mathrm{mg}$ for $\mathrm{Ca}$, per $\mathrm{kg}$ of body weight. The sum of the maintenance and growth requirements (of soft tissue and bone) thus provides apparent digestible $\mathrm{P}$ and $\mathrm{Ca}$ requirements. In fact, the ratio increased with body weight because protein deposition that represents about $30-40 \%$ of the body $\mathrm{P}$ decreases while bones continue to grow after $70 \mathrm{~kg}$ of BW. These can be converted to standardized or total requirements.

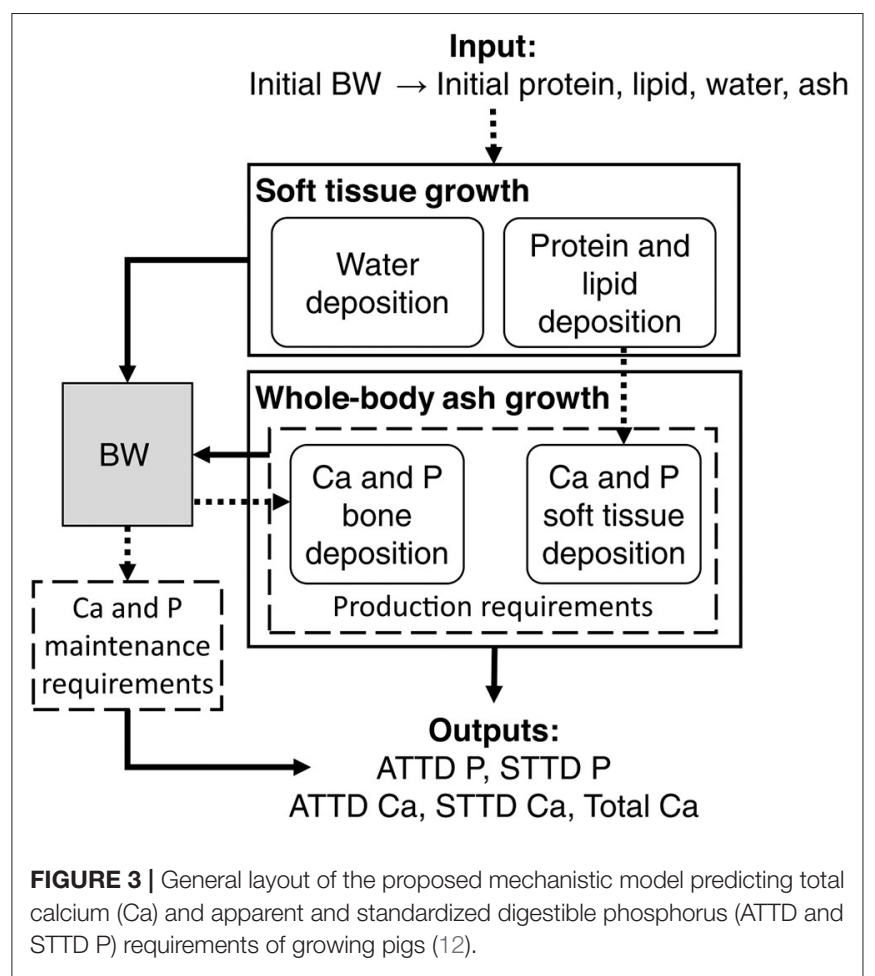

Results confirm the need for a non-fixed Ca:P requirement ratio (Table 1). This model has the additional advantage of being adaptable to different production objectives such as $100 \%$ or $85 \%$ mineralization, without decreasing the share of $\mathrm{Ca}$ or $\mathrm{P}$ destined for soft tissues. Although a single deposition potential has been established, it will become necessary to consider animal genetics $(93,94)$ and/or sex in further validations of the model. The sensitivity analysis of the model showed that protein deposition influenced ATTD-P variance by $15 \%$ for pigs at $30 \mathrm{~kg}, 6 \%$ at $60 \mathrm{~kg}$, and $1 \%$ at $120 \mathrm{~kg}$ based on protein deposition variation in previous trials (12). The decrease in the influence of protein deposition on $\mathrm{P}$ with $\mathrm{BW}$ increase coincides with the linear increase in bone deposition. Moreover, the ATTD-P variance associated with protein deposition at $30 \mathrm{~kg}$ shows that animal growth will have a major impact on $\mathrm{P}$ recommendations.

\subsection{Toward More Efficient Degradation of Phytate Phosphorus}

\subsubsection{Description of Phytases}

Phytases, or myo-inositol hexaphosphate phosphohydrolases, are enzymes that hydrolyze phytic acids and release the phosphate groups (55). In growing pigs, there are 4 sources of phytase: (1) the mucosa of the small intestine, (2) microorganisms in the large intestine, (3) ingested plant matter, and (4) exogenous phytase added to the feed. A unit of phytase activity is defined as the release of $1 \mu \mathrm{mol}$ of inorganic $\mathrm{P}$ per minute in a solution containing $5.1 \mathrm{mmol}$ of sodium phytate per liter at $\mathrm{pH} 5.5$ and $37^{\circ} \mathrm{C}$ (95). Low endogenous phytase activity is observed in the proximal part of the pig intestine, but about $20 \%$ of the phytic $\mathrm{P}$ would nevertheless be potentially absorbable $(72,76,77)$. Some 
TABLE 2 | Characteristics of some commercial microbial phytases.

\begin{tabular}{|c|c|c|c|c|c|c|}
\hline Product & Origin & Expression & Type $^{a}$ & pH optima & $\mathrm{IP}_{6}$ degradation $^{\mathrm{b}}$ & Yearc $^{c}$ \\
\hline Natuphos $^{\circledR}$ & A. Niger & A. Niger & 3 & $2 ; 5-5.5$ & 503 & 1990 \\
\hline Allzyme ${ }^{\circledR}$ SSF & A. Niger & A. Niger, & 3 & 6 & & \\
\hline Finase $^{\circledR} \mathrm{P} / \mathrm{L}$ & A. Niger & Trichoderma reesei & 3 & 2.5 & & \\
\hline Ronozyme ${ }^{\circledR} \mathrm{P}$ & Peniophora lycii & Aspergillus oryzae & 6 & $4-4.5$ & 480 & 2002 \\
\hline Phyzyme ${ }^{\circledR}$ XP & Escherichia coli & Schizosaccharomyces pombe (ATCC 5233) & 6 & 4.5 & 140 & 2003 \\
\hline OptiPhos $^{\circledR}$ & Escherichia coli & Pichia pastoris & 6 & $3.4 ; 5.0$ & & 2006 \\
\hline Quantum $^{\mathrm{TM}}$ & Escherichia coli & Pichia pastoris & 6 & 4.5 & 148 & 2007 \\
\hline Ronozyme ${ }^{\circledR}$ Hiphos & Citrobacter braakii & Aspergillus oryzae & 6 & $4-5$ & 269 & 2010 \\
\hline Quantum ${ }^{\circledR}$ Blue & Escherichia coli & Trichoderma reesei & 6 & $4-5$ & 211 & 2012 \\
\hline Axtra $^{\circledR} \mathrm{PHY}$ & Buttiauxella sp. & Trichoderma reesei & 6 & $3.5-4.5$ & 129 & 2013 \\
\hline Natuphos ${ }^{\circledR} \mathrm{E}$ & $\begin{array}{l}\text { Hybrid phytase (Hafnia sp., Yersinia sp. et } \\
\text { Buttiauxella sp) }\end{array}$ & A. Niger & 6 & $4-5$ & & 2016 \\
\hline
\end{tabular}

Table 2 is not an exhaustive list and represents only a few of the currently available commercial phytases, adapted from Dersjant-Li et al. (95, 97), and Lei et al. (98).

a 3 or 6 phytase.

${ }^{b}$ Phytase activity needed to achieve $50 \%$ reduction in IP6, with high buffer volume.

${ }^{c}$ Year of the commercial launch.

plant raw materials have their own phytasic activity. This one is more or less important according to the ingredient and the part used $(14,84)$. Phytasic activity is higher in some cereals such as rye, triticale, wheat, or barley than in cereals richer in proteins (19). Plant phytase is sensitive to heat (more than microbial phytases), since its activity is partially or completely inactivated after high temperature treatment $\left(>70^{\circ} \mathrm{C}\right)$ such as those for pelleting $(18,84,96)$. It is why in INRA-AFZ feed tables (19) two values are given for P digestibility, one which takes account of the effect of endogenous phytase to be used when feed is given as meal, and a second without considering the effect of endogenous phytase to be used when the feed is pelleted. Therefore, the most promising phytase sources remains the exogenous phytase.

\subsubsection{New Generations of Exogenous Phytases}

The first exogenous phytase was marketed in 1991 in the Netherlands, the first country to introduce strict regulations intended to limit $\mathrm{P}$ discharges from pig and poultry farming. The use of phytases then accelerated following the introduction of similar legislation in other countries and the ban on the use of animal byproducts in Europe (18). These enzymes were isolated first from fungi (Table 2), then new techniques allowed the production of phytases by bacteria and yeast, leading to the second generation of phytases. The common commercial phytases are obtained from cultures of Aspergillus niger, Peniophora lycii (fungi, 3-phytase), and Escherichia coli (bacteria, 6-phytase). In pigs, bacterial phytase has been found to be more effective than fungal phytase $(78,99)$. This explains why fungial phytases were supplanted in the early 2000 s by 6 -phytases produced by Escherichia coli. Other second-generation phytases obtained from cultures of Citrobacter braakii, Buttiauxella spp. and even hybrid forms soon followed (Table 2). Third generation phytases with up to 8 amino acid substitutions in the E. coli enzyme have better thermostability (100). The presence of plant phytase reduces the response to added exogenous phytase (18).
New generation phytases developed through genetic engineering release more P (101). Exogenous phytases also increase Ca availability (32) but the underlying mechanism remains to be determined. $\mathrm{P}$ and $\mathrm{Ca}$ digestion in pigs has been modeled, integrating interactions, the different chemical forms, and the effect of phytase (71). Dissociation of Ca phytates at gastric $\mathrm{pH}$ is presumed in this model has showed in vitro (102). By increasing the proportion of phytate degraded by phytase in the upper digestive tract, less $\mathrm{Ca}$ should form insoluble complexes with phytate in the small intestine where $\mathrm{pH}$ is favorable and therefore more should remain available for absorption. However, we have not seen validation of this hypothesis in vivo and the exact mode of action of phytase on Ca remains unclear, but undoubtedly have an impact in vivo. Phytases preferentially release the position 5 and 6 phosphates, which have the highest affinity for cations such as $\mathrm{Ca}$, rather than dephosphorylating phytate completely (103). As a result, the phytase doses that are now commonly used would increase $\mathrm{Ca}$ availability more than $\mathrm{P}$ availability, at a ratio of about 2 , whereas high doses would sustain $\mathrm{P}$ release while Ca release reached an asymptote (103).

\subsubsection{Factors Influencing the Efficiency of Exogenous Phytases}

For optimal action, phytic acid must be hydrolyzed upstream from the sites of absorption of $\mathrm{P}$ and other minerals such as $\mathrm{Ca}$, $\mathrm{Zn}$, and Fe. $\mathrm{P}$ is absorbed mostly in the upper small intestine $(5,51)$. Hydrolysis in the stomach is therefore ideal, meaning that the enzyme must be sufficiently active at gastric $\mathrm{pH}$ (3.5 in young pigs and lower in older animals (104)). Phytase from $A$. niger works well at $\mathrm{pH} 2$ or 5-5.5, but poorly at porcine gastric $\mathrm{pH}$. The optimal $\mathrm{pH}$ range of new generation phytases has been lowered and in some cases broadened [Figure 4; (105-107)].

To limit the loss of activity, phytases must be made resistant to digestive proteases. Second-generation phytases were better in this sense (P. Lycii vs. E. coli, Figure 5, 106). After 2 h in contact 

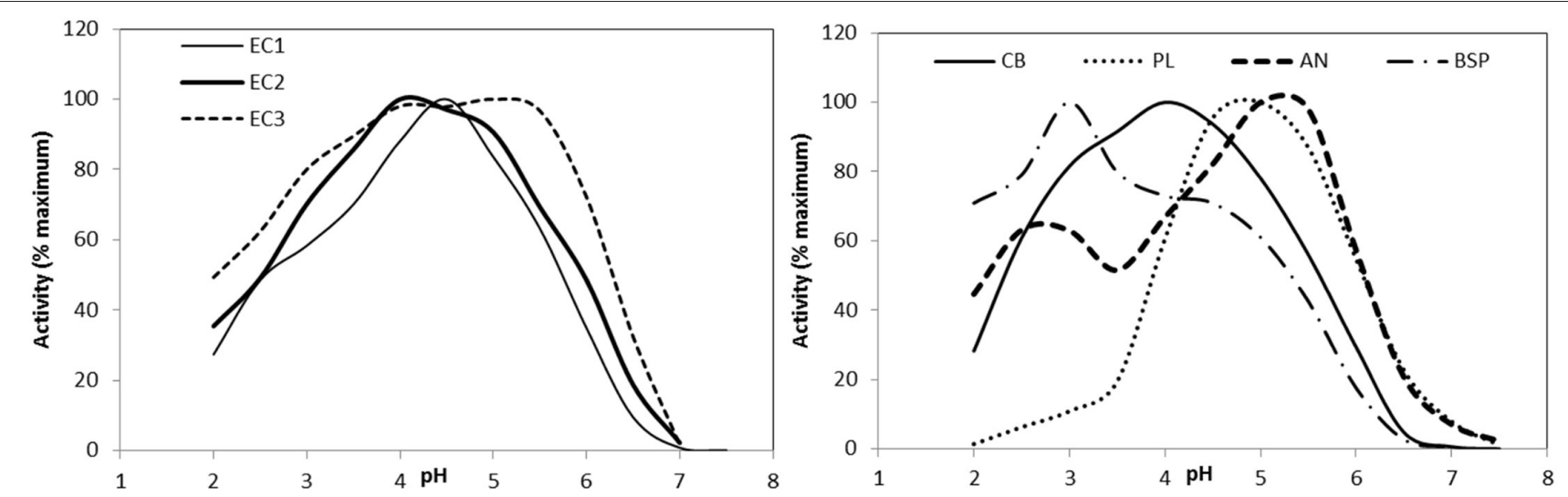

FIGURE 4 | Effect of $\mathrm{pH}$ on phytase activity of the phytase products used in the in vitro degradation model with EC1: Quantum (AB Vista), EC2: Quantum Blue (AB Vista), EC3: Phyzyme XP (Danisco), CB: Ronozyme Hiphos (DSM), PL: Ronozyme NP (DSM), AN: Natuphos (BASF), BSP: AxtraPHY (Danisco). Reprinted with permission from (105). Copyright 2015 American Chemical Society.

with pepsin, E. coli phytases retained $77 \%$ of their initial activity compared to $31 \%$ for an $A$. niger phytase (95).

The ideal temperature of activation of the phytase is between 50 and $60^{\circ} \mathrm{C}$. On the other hand, high temperature treatments $\left(>70^{\circ} \mathrm{C}\right)$ decrease the phytase activity of the feed (108-110). The second-generation $E$. coli phytases lost thermostability compared to the fungal phytases (98), except for a third-generation phytase from E. coli (Phy9X), which is resistant to higher temperatures, up to $75^{\circ} \mathrm{C}(108,111)$. On the other hand, increasing the resistance temperature of phytases can lead to a higher optimal temperature and thus potentially decrease their efficacy at normal pig body temperature (around $39^{\circ} \mathrm{C}$ ) (112).

To be the most useful, phytases must preferentially degrade $\mathrm{IP}_{6}$ and $\mathrm{IP}_{5}$ phytates as quickly as possible. They must, therefore, have a high affinity for the preferred substrate. Second-generation phytases were improved in this sense (112), at least in terms of initial reaction velocity $\left(\mathrm{V}_{\text {max }}\right)$ in vitro with $\mathrm{IP}_{6}$ and $\mathrm{IP}_{5}$ substrates (105).

Despite the improvement in phytases, it is important to understand that they act on soluble phytates. Therefore, the factors that influenced phytate solubility must be control. Certain minerals interfere with phytates. Cations have an inhibitory power related to their affinities for phytic acid but also the insolubility of the complexes they formed. This is measurable as the amount of mineral that causes phytates hydrolysis to drop by $50 \%$ at a given $\mathrm{pH}$ (102). The smaller the amount, the more inhibitory. On this basis, the following ranking has been established (102): at $\mathrm{pH}$ 6: $\mathrm{Fe}^{2+}>\mathrm{Zn}^{2+}=\mathrm{Fe}^{3+}>\mathrm{Mn}^{2+}$ $>>\mathrm{Ca}^{2+}>\mathrm{Mg}^{2+}$ At pH 5: $\mathrm{Fe}^{3+}>\mathrm{Fe}^{2+}>\mathrm{Zn}^{2+}>>\mathrm{Mn}^{2+}>$ $\mathrm{Ca}^{2+}>>\mathrm{Mg}^{2+}$, representatives of the gut $\mathrm{pH}$ in pigs. This inhibitory power represents the affinities of the minerals for phytic acid but also the insolubility of the complexes formed. Reducing the $\mathrm{pH}$ to 4 , which corresponds to gastric $\mathrm{pH}$, strongly reduces the power of all minerals tested. Iron has the greatest potential for inhibition, but to our knowledge, no study of its effect on phytase effectiveness in animal feed has been published. Regarding $\mathrm{Zn}$ and $\mathrm{Cu}$, their supply can be high in piglets with so-called pharmacological levels $(2,500 \mathrm{ppm})$ when used as a

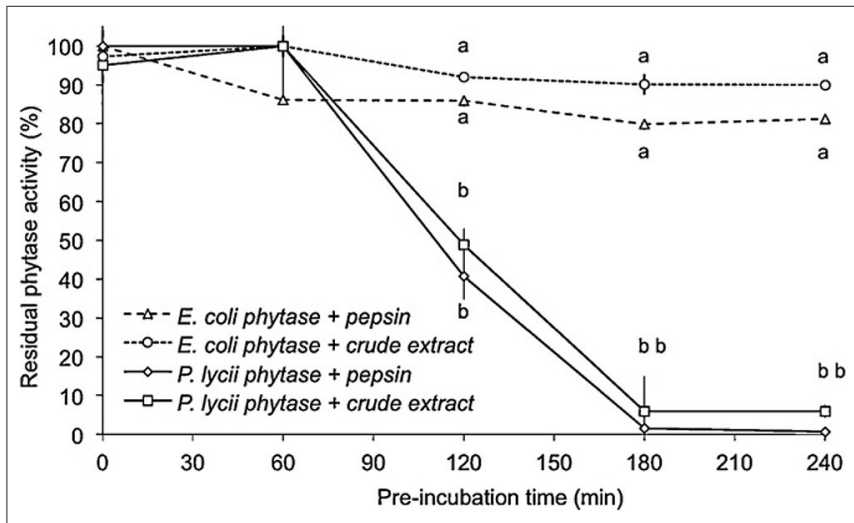

FIGURE 5 | Residual phytase activity of $E$. coli and $P$. lycii phytase after pepsin or gastric crude extract from trout stomach hydrolysis throughout incubation time $(0,60,120,180$, and $240 \mathrm{~min})$. The incubation was performed by adding 1 FTU phytase to a protease solution with $5000 \mathrm{U}$ from porcine pepsin or gastric crude extract from fish, performed at $\mathrm{pH} 2.0(\mathrm{HCl}), 16^{\circ} \mathrm{C}$. The results are plotted as the mean $\pm \mathrm{SE}$ (triplicates). Different letters, for each time, indicate significant differences $(\mathrm{P}<0.05)$ between phytases (106).

growth factor to reduce diarrhea. $\mathrm{Zn}$ has a high complexing power, a single $\mathrm{Zn}$ cation being capable of binding to two phytic acid molecules (113). The effect of $\mathrm{Zn}$ on phytase efficiency has been studied in weaned pigs (6-20 kg). With 1,000 and 3,000 FTU in the diet, zinc oxide at $3,000 \mathrm{mg} / \mathrm{kg}$ decreased the $\mathrm{Ca}$ ATTD by 6 and 9\%, respectively, and the P ATTD by 10 and $16 \%$ in pigs weighing $15-20 \mathrm{~kg}$ (114). In young pigs weighing $7-13 \mathrm{~kg}, \mathrm{P}$ release by phytase was reduced by $30 \%$ when the dietary $\mathrm{Zn}$ content was $1,500 \mathrm{mg} / \mathrm{kg}$ (115). The effect of $\mathrm{Cu}$ on phytase is less clear. $\mathrm{Cu}$ phytates appear to be soluble at neutral $\mathrm{pH}$ (113), suggesting no effect. An in vitro study of $\mathrm{Cu}$ at $62.5 \mathrm{mg} / \mathrm{kg}$ and $\mathrm{pH} 5.5$ suggests that $\mathrm{P}$ release from phytase may decrease by $2-30 \%$ depending on the source of the $\mathrm{Cu}$ (116). At $500 \mathrm{mg} / \mathrm{kg}$, the decreases ranged from 5 to $75 \%$. At $\mathrm{pH}$ 6.5, the decreases were even more marked but were almost non-existent at $\mathrm{pH}$ 2.5. The most likely explanation for these 


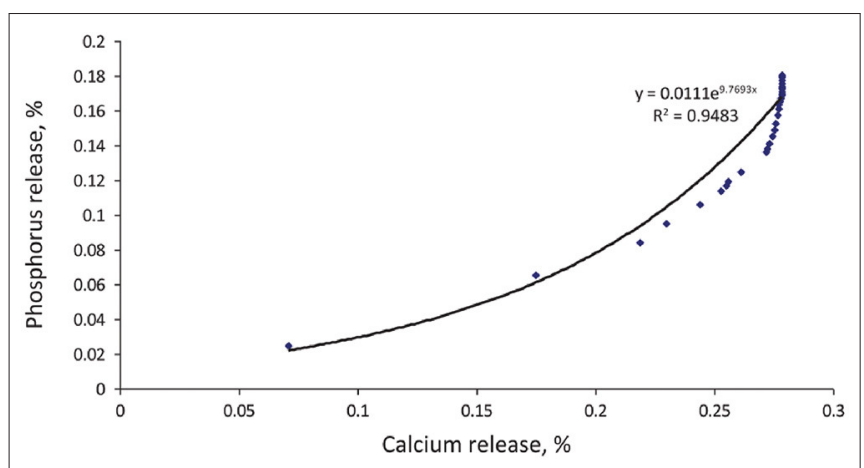

FIGURE 6 | Theoretical relationship between $\mathrm{P}$ release from phytate and associated $\mathrm{Ca}$ value showing disproportionate extra phosphoric effect with initial destruction of the higher esters (103).

observations would be formation of insoluble phytic acid-Cu complexes at higher $\mathrm{pH}$, which is of some concern given the $\mathrm{pH}$ of the porcine gut (116-118). In pigs weighing 6-22 kg, $\mathrm{P}$ digestibility was greater with methionine-chelated $\mathrm{Cu}$ than with $\mathrm{Cu}$ sulfate (118). Chelated $\mathrm{Cu}$ would be more stable in the upper gastrointestinal tract and less available to form complexes with phytic acid; thus there would be a better release of absorbable phosphate $(116,119)$. Tests of the effect of $\mathrm{Zn}$ and $\mathrm{Cu}$ form and concentration on $\mathrm{Ca}$ and $\mathrm{P}$ digestibility in pigs weighing 6-22 kg showed that the form of $\mathrm{Cu}$ had no effect, while the form of $\mathrm{Zn}$ did (117).

$\mathrm{Ca}$ is ranked as less inhibitory but is incorporated into feed at much higher concentrations than $\mathrm{Zn}, \mathrm{Cu}$, or $\mathrm{Fe}$. As a result, $\mathrm{Ca}$ forms a significant proportion of insoluble phytates, frequently with $\mathrm{Zn}(120)$. Because the recent phytases have a higher affinity for $\mathrm{IP}_{6}$ and $\mathrm{IP}_{5}$, which have higher affinities for $\mathrm{Ca}$, the ratio of $\mathrm{Ca}: \mathrm{P}$ released using second and third generation phytases is around 2 at $500 \mathrm{FTU} / \mathrm{kg}$ (Figure 6) and decreases as phytase activity increases $(103,121,122)$. The phytase levels practiced in the field may therefore lead to an increase in the digestible $\mathrm{Ca}: \mathrm{P}$ ratio. Trials have shown phytase effectiveness to decrease as the Ca:P ratio increases in the feed (123-125) albeit without comparison to phytase-free diets, making it impossible to know whether the effect of $\mathrm{Ca}$ was on phytase or on $\mathrm{P}$ absorption (126). When the ratio of $\mathrm{Ca}$ to total $\mathrm{P}$ was increased from 1.2 to 1.8 , pigs grew more slowly regardless of the presence of phytase, suggesting a specific effect due to Ca rather than an influence on phytase efficacy in releasing $\mathrm{P}$ (78). In trials conducted with $\mathrm{P}$ at requirement levels, $\mathrm{P}$ digestibility decreased slightly as the Ca:P ratio increased from 1.2 to 1.9 but was indifferent to phytase (79). Furthermore, urinary excretion of $\mathrm{P}$ was 5-fold higher at a Ca:P ratio of 1.2, due to the lack of $\mathrm{Ca}$ for deposition of $\mathrm{P}$ in bone. Nor was any effect of $\mathrm{Ca}$ on phytase efficacy found when animals were fed above the $\mathrm{P}$ requirement (127). A high Ca:P ratio therefore does not seem to have a direct effect on phytase efficacy in releasing $\mathrm{P}$ but rather on $\mathrm{P}$ absorption and retention, possibly going so far as to cause a $\mathrm{P}$ deficiency and ultimately poorer growth regardless of the presence of phytase $(18,79)$.

\subsection{Depletion-Repletion Strategy}

Animals have a survival strategy to overcome some mineral deficiencies by enhancing digestion and increasing the efficiency of utilization of the deficient nutrient (128). In several species, dietary restriction of $\mathrm{Ca}$ and $\mathrm{P}$ results in increased intestinal absorption, renal reabsorption, and deposition and mobilization in bone tissue (1). The effects of dietary $\mathrm{Ca}$ restriction and recovery processes on bone metabolism were studied decades ago in rats (129-131) and humans (132). The findings suggest that bone has ways of replenishing losses due to the use of mineral reserves and that parathyroid hormone and vitamin $\mathrm{D}$ play a role in the mechanisms. Bone accretion, intestinal absorption, and renal reabsorption of minerals are under hormonal regulations described in Figure 7.

The Ca depletion-repletion strategy is already used to prime dairy cows for high Ca demand during early lactation (133) and to prevent milk fever. By feeding a Ca-deficient ration for a few weeks before the start of lactation, regulatory mechanisms that maintain blood $\mathrm{Ca}$ levels (increased intestinal absorption and renal reabsorption) are activated $(133,134)$. A few days before calving, when the demand for Ca becomes very high, the cows then receive more $\mathrm{Ca}$ (134), and the shortfall between the requirement and $\mathrm{Ca}$ absorbed is smaller because of the effect of priming on parathyroid hormone. The animal is also better prepared to draw upon bone $\mathrm{Ca}$ as needed to maintain blood Ca levels and thus prevent milk fever. Similar regulatory mechanisms allow maintenance of $\mathrm{P}$ levels, and these can be exploited to increase dietary $\mathrm{P}$ utilization in growing animals and hence the sustainability of livestock farms from the environmental perspective. The idea underlying the depletionrepletion strategy is therefore to trigger regulatory mechanisms during the depletion phase to induce an increase in $\mathrm{P}$ utilization efficiency without affecting growth performance (1). In the case of $\mathrm{P}$ and $\mathrm{Ca}$, the mineral content of the body or of a specific bone is monitored using X-ray absorptiometry [DXA, (135)]. During depletion in growing pigs, body bone mineral content continues to increase, but bone accretion is decreased compared to control pigs, leading to reduced bone mineral content.

When $\mathrm{P}$ supply is intentionally below the estimated requirement of the animals, the level of Ca is generally decreased at the same time to avoid the deleterious effects of a high digestible $\mathrm{Ca}: \mathrm{P}$ ratio on $\mathrm{P}$ absorption. When animals thus primed are fed the repletion diet, which provides $\mathrm{P}$ at least at the requirement level, the deficit overcome. This allows an overall reduction in dietary $\mathrm{P}$ intake during the rearing phase. Depletion-repletion studies of growing animals such as pigs $(8,10,136)$ and chickens (137-141) led to effectively increasing $\mathrm{P}$ utilization and limiting excretion without compromising animal well-being and performance. Some authors $(9,142)$ have focused on improvements to bone health; these studies have led to better understanding of the deleterious effects of short-term dietary $\mathrm{Ca}$ deficits during growth on long-term bone mineralization. The main trials performed with pigs are summarized in Table 3.

When $\mathrm{Ca}$ is deficient, the $\mathrm{Ca}$ regulation calls for parathyroid hormone, which is a hypercalcemic hormone that increases dietary $\mathrm{Ca}$ utilization, but with a concomitant hypophosphoremic effect due to renal excretion of P (144). 


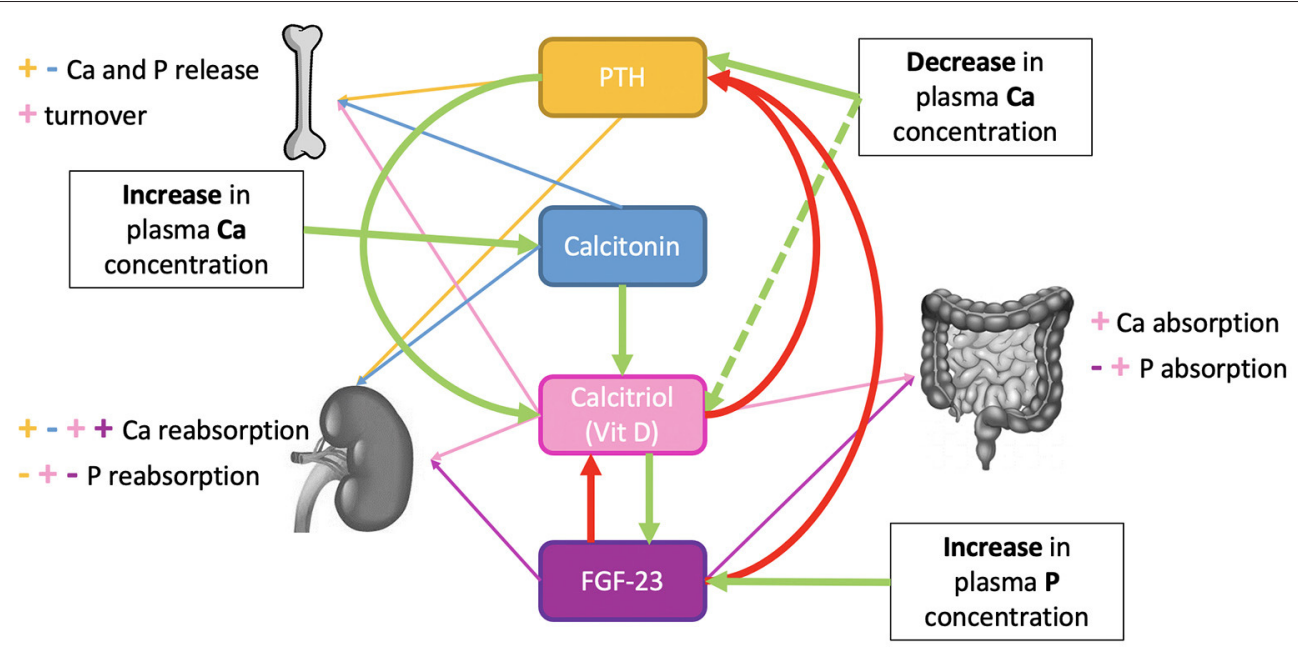

Stimulation

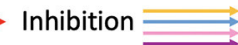

Actions

FIGURE 7 | Hormonal regulation of phosphocalcic metabolism.

Ca deficiency must therefore be avoided. In growing pigs, it has been found to reduce the expression of genes related to $\mathrm{P}$ reabsorption in the kidney, favoring $\mathrm{P}$ excretion in urine (145). P depletion in the range of $30-40 \%$ and slightly lower for $\mathrm{Ca}$ induces demineralization of the same order in the whole body and vertebrae as measured by DXA (Table 3). The trial conducted by Aiyangar et al. (9) shows greater demineralization with a higher $\mathrm{Ca}$ deficiency. The metacarpus appears to demineralize less (5-10\%) than the whole body or vertebrae (10), whereas the femur responds like the whole body. Bone reserve depletion measured thus depends primarily on the degree of dietary depletion and on the bone region studied.

Several studies have shown that this strategy works and increases bone mineral content (BMC) gains and digestible $\mathrm{P}$ utilization when animals are fed a repletion diet (at requirement or above). The gain of BMC in L2 to L4 vertebrae in depleted animals exceeded those in non-depleted control pigs by $56 \%$ during a first 28 -day repletion phase and $15 \%$ during a second repletion of the same length (8) and by $29 \%$ after a 28 -day repletion and $11 \%$ after a 56-day repletion in another study (Figure 8; 136). The corresponding increases in digestible $\mathrm{P}$ utilization estimated as deposition vs. intake were $20-50 \%$ with bone deficit recovery in 28-56 days for the whole body and in 28 days for vertebrae. The shorter time for vertebrae could be due to their high percentage of trabecular tissue, which is more sensitive than cortical tissue to mineral deficiencies (146). Furthermore, in pigs, bone mineralization is faster in the trunk from 3 to $30 \mathrm{~kg}$ of BW than in other parts of the skeleton (147). In a study using the common dosage of $750 \mathrm{FTU} / \mathrm{kg}$ without phosphate, thus $40 \%$ below the requirement, the deficit was recovered in 27 days on the repletion diet with a $47 \%$ increase in whole body BMC gain (143). Overall, the depletion-repletion strategy reduced dietary phosphate use and $\mathrm{P}$ release by about $40 \%$. In contrast, the repletion diet has failed to restore bone mineralization in at least two porcine studies $(9,142)$.

Phosphocalcic regulations occur in the gut, kidney, and bone $(32,148)$. Ca absorption may increase by $27 \%$ upon repletion compared to control animals receiving the same feed (8). Osteocalcin, derived from newly synthesized bone and thus an indicator of osteoblastic activity and hence increased bone accretion (149), has been found to increase during the repletion phase (10). The physiological mechanisms underlying animal responses to the depletion-repletion strategy remain poorly understood. It, nevertheless, appears that adequate bone mineralization and growth performance can be achieved at decreased $\mathrm{P}$ intake and excretion through improved $\mathrm{P}$ utilization.

\section{MITIGATION STRATEGIES: COMPARISON AND PERSPECTIVES}

The mitigation of the environmental footprint of $\mathrm{P}$ in pig production both refers to the optimization of the use of phosphates, which are a non-renewable resource that must be extracted and transported, and to the minimization of its excretion especially in regions with high production density. Some strategies of mitigation have been proposed in the previous sections.

The potential for decreasing $\mathrm{P}$ excretion with phytase is well known (18). Its potential depends mainly on a precise nutritional matrix. First, a precise estimation and utilization of the P matrix is crucial. The Ca matrix has recently been shown to be of great importance because, on the one hand, an excess of soluble $\mathrm{Ca}$ can decrease the P digestibility (78) and, on the other hand, in case of $\mathrm{Ca}$ deficiency, the $\mathrm{P}$ is not retained and is excreted in the urine (79). In recent trial with microbial phytases (500 FTU), Lagos et al. (150) showed a drop of $37 \%$ in the total P excretion, 
TABLE 3 | Effect of depletion-repletion strategy on bone mineralization of growing pigs.

Depletion period

Repletion period

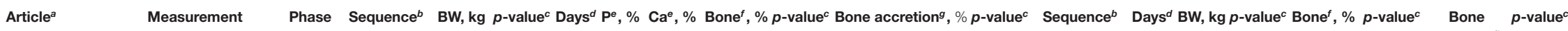
accretion

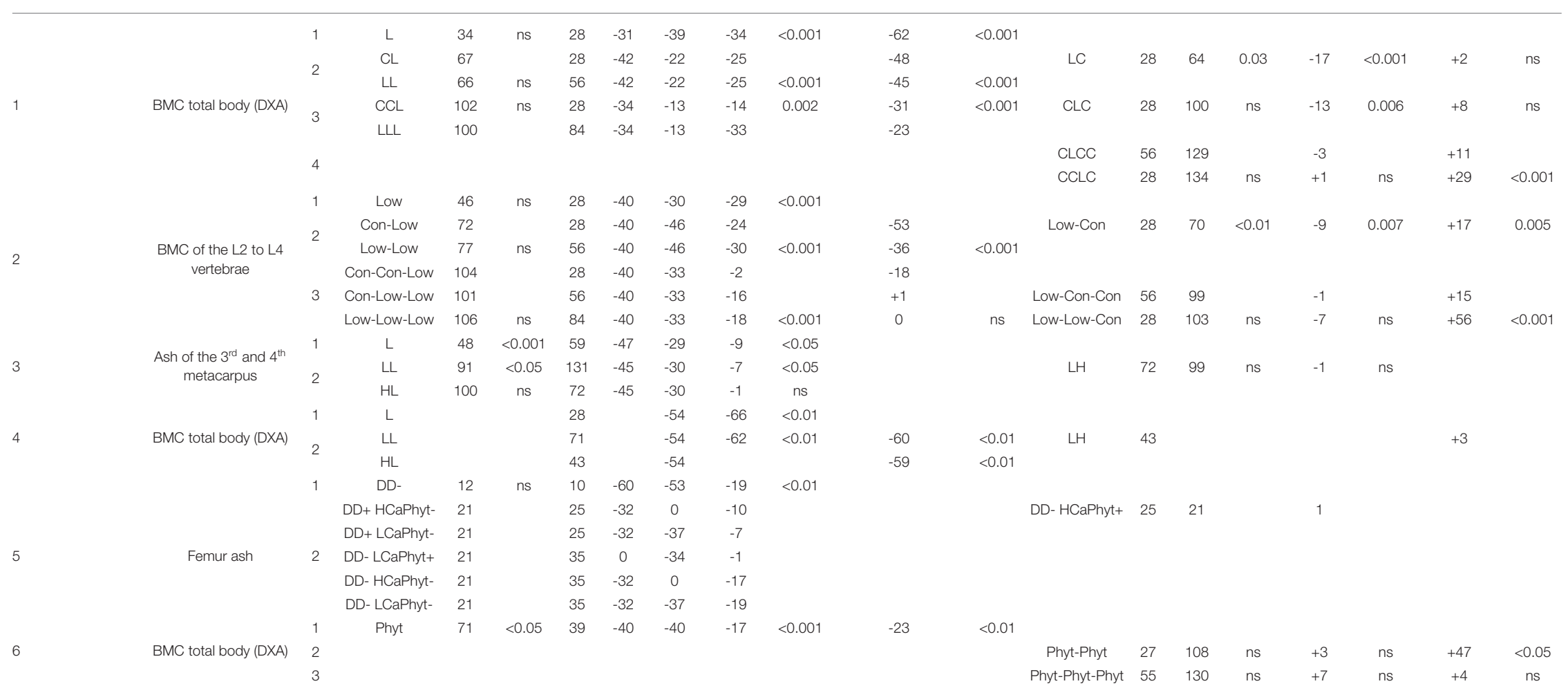

${ }^{a}$ Article 1 : Gonzalo et al. (136), article 2 : Létourneau-Montminy et al. (8), article 3 : Varley et al. (10), article 4 : Aiyangar et al. (9), article 5 : Létourneau-Montminy et al. (79), article 6 : Lautrou et al. (143).

${ }^{b}$ Sequences of depletion and repletion as named in the original articles.

${ }^{c} p$-value of the statistical analysis of the control vs. the studied group, for the variable of the previous column.

${ }^{d}$ Duration of the depletion or repletion.

${ }^{e} \mathrm{P}$ or Ca depletion against the control.

${ }^{f}$ Difference of the state of the bone at the end of the phase between the control vs. the studied group, according to the measurement.

${ }^{g}$ Difference of the bone accretion measurement between the control and the studied group. 


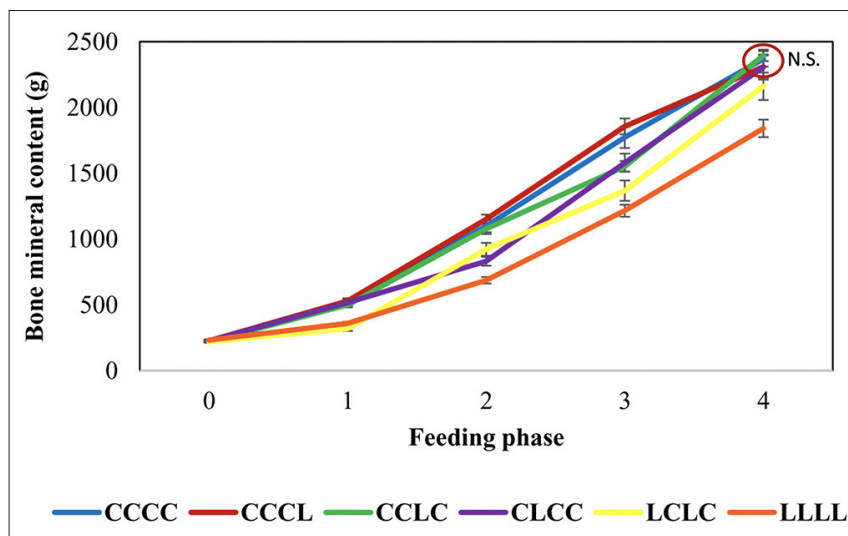

FIGURE 8 | Body bone mineral content of growing pigs feeding depletion-repletion diets (145).

and a reduction of $6.1 \mathrm{~g} / \mathrm{kg}$ monocalcium phosphate supply, for $60 \mathrm{~kg}$ BW pigs. Besides, Almeida and Stein (55) showed that the total P excretion decreases up to $51 \%$ with 685 FTU at 15 $\mathrm{kg}$ of BW, and monocalcium phosphate supply is reduced up to $8 \mathrm{~g} / \mathrm{kg}$.

The depletion-repletion strategy also led to a decrease of the phosphate input and the $\mathrm{P}$ excretion. In Gonzalo et al. (136)'s trial, a depletion period of 28 days (L) resulted in a decrease of $\mathrm{P}$ supply from 8 to $12 \%$, and 2 separate depletion periods of 28 days (LCLC, C being a 28 days phase of feeding control diet) resulted in a reduction of $12 \%$ of $\mathrm{P}$ input. The excretion of $\mathrm{P}$ in the CLCC, CCLC, and LCLC groups decreased of 15,13 , and $16 \%$, respectively, compared to the control. The decrease of $\mathrm{P}$ excretion was greater than the decrease of $\mathrm{P}$ input thanks to animals utilizing $\mathrm{P}$ more efficiently during the depletion and the repletion periods. With $\mathrm{P}$ total collection of feces and urine, Létourneau-Montminy et al. (8) showed that a depletion of 56 days can lead to a $\mathrm{P}$ excretion decrease of $19 \%$ with a diminution of $\mathrm{P}$ intake of $23 \%$. As seen previously, few authors tested depletionrepletion strategies on growing pigs and the results differ in terms of bone mineralization compensation (145). There is a lack of data to precisely defined an ideal strategy of depletion repletion (depletion duration, age, intensity). The study of underlying mechanisms, such as hormonal regulations, will certainly help to reach this objective to reduce phosphate input without compromising bone mineralization and to apply this strategy on farm. Nevertheless, a reduction of $15-20 \%$ of both phosphate use and $\mathrm{P}$ excretion may be achieved with depletionrepletion strategy.

The strategy of depletion-repletion can also be combined with phytase. Lautrou et al. (143) tried to evaluate the effect of a zero phosphate diet on the growth of pigs and the environment. The use of phytase did not meet the full extent of the $\mathrm{P}$ requirements for pigs during the first growing phase of 39 days, but phytase provided enough $\mathrm{P}$ during the 2 next phases. This strategy led to a drop of $66 \%$ in $\mathrm{P}$ excretion during the 2 first phases (the data are not available for the last one), and a reduction in monocalcium phosphate supply of 18.71, 9.52, and $7.17 \mathrm{~g} / \mathrm{kg}$ in Phases 1, 2, and 3 , respectively. This trial showed that there is an opportunity to feed growing pigs from 30 to $130 \mathrm{~kg}$ without adding any mineral phosphates. This success has to be confirmed and always requires a well-defined phytase matrix, particularly to mitigate the risks associated with the depletion phase.

In a simulation, Pomar et al. (151) showed that precision feeding, a strategy in development that allow to feed pigs with diets tailored daily to each individual's nutrient requirements, could reduce $\mathrm{P}$ excretion by $38 \%$. A recent study compared the $\mathrm{P}$ excretion of pigs under conventional or precision feeding (152). The individual and daily feeding system (based on estimated lysine requirement) led to a decrease of $27 \%$ in $\mathrm{P}$ excretion compared to the group phase feeding system. In this trial, phytase was used but not compared with a control without phytase. The combination of precision feeding with phytase and a depletion-repletion strategy has not been tested yet, but after the synergy observed with the phytase and depletion-repletion strategy, combining these 3 methods seems a promising strategy that could lead to an even greater reduction of $\mathrm{P}$ excretion.

\section{CONCLUSIONS}

This review has shown that it is still possible to improve $\mathrm{P}$ utilization in swine and to improve the sustainability of the industry by mitigating phosphorus' impact on the environment. The first step is to precisely estimate the $\mathrm{P}$ and $\mathrm{Ca}$ content of feedstuffs and each animal's total diet. The second step is to use a robust multicriteria modeling approach to establish animal requirements. The new generation of phytases may provide a strategy to increase $\mathrm{P}$ utilization by pigs by providing a precise estimation of the equivalences and interfering factors and maximizing the solubility of phytates. A depletion-repletion strategy to prime animals to make them more efficient is also promising, but still requires testing to refine it and better understand the underlying mechanisms. Finally, precision feeding, a strategy in development that permits feeding pigs with diets that are tailored daily to each individual's nutrient requirements, shows possibilities to reduce more $\mathrm{P}$ excretion, and will undoubtedly be employed once the $\mathrm{P}$ requirements will be well defined by a robust modeling approach.

\section{AUTHOR CONTRIBUTIONS}

ML wrote the original draft. AN, J-YD, CP, PS, and M-PL reviewed the article and add new ideas and participate to improve the structure of the document. All authors contributed to the article and approved the submitted version. 


\section{REFERENCES}

1. Suttle NF. Mineral nutrition of livestock, 4th ed, Suttle N, editor. Wallingford: CABI (2010). Available online at: http://www.cabi.org/cabebooks/ebook/20103291114

2. Van Enk RJ, Acera LK, Schuiling RD, Ehlert P, De Wilt JG, De Vries CK, et al. The Phosphate Balance: Current Developments and Future Outlook. (2011). Available online at: http://www.innovatienetwerk.org/sitemanager/ downloadattachment.php?id=TnV9h_IU2899_OkhJmHC1

3. Heckenmüller M, Narita D, Klepper G. Global availability of phosphorus and its implications for global food supply: An economic overview. Kiel Working Paper, No. 1897, Kiel Institute for the World Economy (IfW), Kiel (2014).

4. Yang XE, Wu X, Hao HL, He ZL. Mechanisms and assessment of water eutrophication. J Zhejiang Univ. (2008) 9:197-209. doi: 10.1631/jzus.B0710626

5. Crenshaw TD. Calcium, phosphorus, vitamin $\mathrm{d}$, and vitamin $\mathrm{k}$ in swine nutrition. In: Lewis AJ. Southern LL, editors. Swine Nutrition, 2nd ed. New York, NY: CRC Press (2001). p. 187-212.

6. Heaney RP. Phosphorus nutrition and the treatment of osteoporosis. Mayo Clin Proc. (2004) 79:91-97. doi: 10.4065/79.1.91

7. Selle PH, Cowieson AJ, Ravindran V. Consequences of calcium interactions with phytate and phytase for poultry and pigs. Livestock Sci. (2009) 124:126-41. doi: 10.1016/j.livsci.2009.01.006

8. Létourneau-Montminy MP, Pomar C, Lovatto PA. Apparent total tract digestibility of dietary calcium and phosphorus and their efficiency in bone mineral retention are affected by body mineral status in growing pigs. J Anim Sci. (2014) 92:3914-24. doi: 10.2527/jas.2013-7320

9. Aiyangar AK, Au AG, Crenshaw TD, Ploeg HL. Recovery of bone strength in young pigs from an induced short-term dietary calcium deficit followed by a calcium replete diet. Med Eng Phys. (2010) 32:1116-23. doi: 10.1016/j.medengphy.2010.08.001

10. Varley PF, Sweeney T, Ryan MT, O’Doherty JV. The effect of phosphorus restriction during the weaner-grower phase on compensatory growth, serum osteocalcin and bone mineralization in gilts. Livestock Sci. (2011) 135:282-8. doi: 10.1016/j.livsci.2010.07.025

11. Létourneau-Montminy MP, Narcy A, Dourmad JY, Crenshaw TD, Pomar C. Modeling the metabolic fate of dietary phosphorus and calcium and the dynamics of body ash content in growing pigs. J Anim Sci. (2015) 93:1200-17. doi: $10.2527 /$ jas.2014-8519

12. Lautrou M, Pomar C, Dourmad JY, Narcy A, Schmidely P, LétourneauMontminy MP. Phosphorus and calcium requirements for bone mineralisation of growing pigs predicted by mechanistic modelling. Animal. (2020) 14:s313-22. doi: 10.1017/S1751731120001627

13. Pomar C, Pomar J, Rivest J, Cloutier L, Létourneau-Montminy MP, Andretta I, et al. Estimating real-time individual amino acid requirements in growingfinishing pigs: towards a new definition of nutrient requirements in growingfinishing pigs? In: Sakomura NK, Gous R, Kyriazakis I, Hauschild L, editors. Nutritional Modelling for Pigs and Poultry. Wallingford, UK: CAB International (2015). p. 157-74. doi: 10.1079/9781780644110.0157

14. Humer E, Schwarz C, Schedle K. Phytate in pig and poultry nutrition. J Anim Physiol Anim Nutr. (2015) 99:605-25. doi: 10.1111/jpn.12258

15. Pointillart A. Phytates, phytases : leur importance dans l'alimentation des monogastriques. INRAE Prod Anim. (1994) 7:29-39. doi: 10.20870/productions-animales.1994.7.1.4155

16. Pontoppidan K, Pettersson D, Sandberg AS. The type of thermal feed treatment influences the inositol phosphate composition. Anim Feed Sci Technol. (2007) 132:137-47. doi: 10.1016/j.anifeedsci.2006.03.008

17. Feil B. Phytic acid. J New Seeds. (2001) 3:1-35. doi: 10.1300/J153v03n03_01

18. Selle $\mathrm{PH}$, Ravindran V. Phytate-degrading enzymes in pig nutrition. Livestock Sci. (2008) 113:99-122. doi: 10.1016/j.livsci.2007.05.014

19. Sauvant D, Perez JM, Tran G. Tables INRA-AFZ de Composition et de Valeur Nutritive des matières premières destinées aux animaux d'élevage: 2ème édition. Versailles: INRA Editi Edition (2004).

20. NRC. Nutrient Requirements of Swine, 11th Rev. Washington, DC: National Academies Press (2012).

21. Wise A. Dietary factors determining the biological activities of phytase. Nutr Abstr Rev. (1983) 53:791-806.
22. Angel R, Tamim NM, Applegate TJ, Dhandu AS, Ellestad LE. Phytic acid chemistry: influence on phytin-phosphorus availability and phytase efficacy. J Appl Poultry Res. (2002) 11:471-80. doi: 10.1093/japr/11. 4.471

23. Vohra P, Gray GA, Kratzer FH. Phytic acid metal complexes. Proce Soc Exp Biol Med. (1965) 120:447. doi: 10.3181/00379727-120-30559

24. Vasca E, Materazzi S, Caruso T, Milano O, Fontanella C, Manfredi C. Complex formation between phytic acid and divalent metal ions: a solution equilibria and solid state investigation. Anal Bioanal Chem. (2002) 374:173-8. doi: 10.1007/s00216-002-1469-6

25. Taylor TC. The availability of the calcium and phosphorus of plant materials for animals. Proc Nutr Soc. (1965) 24:105-12. doi: 10.1079/PNS19650017

26. O'Dell BL, De Boland A. Complexation of phytate with proteins and cations in corn germ and oil seed meals. J Agric Food Chem. (1976) 24:804-8. doi: 10.1021/jf60206a034

27. Greiner R, Konietzny U. Update on characteristics of commercial phytases. Int Phytase Summit. (2012) 96-107.

28. Bleukx W. Production et qualité nutritionnelle des phosphates alimentaires. Prod Anim. (2005) 18:169-73. doi: 10.20870/productions-animales.2005.18.3.3521

29. Viljoen J. Quality of feed phosphate supplements for animal nutrition. S Afr J Anim Sci. (2001) 2:13-19.

30. De Groote G, Lippens M, Jongbloed AW, Meschy F. Study on the Bioavailability of Major and Trace Minerals. Technical report (2002).

31. IFP. Evaluating Feed Phosphates. (2021). Available online at: https:// www.feedphosphates.org/index.php/guides/11-guides/13-evaluating-feedphosphates

32. González-Vega JC, Stein HH. - Invited review - calcium digestibility and metabolism in pigs. Asian Aust J Anim Sci. (2014) 27:1-9. doi: 10.5713/ajas.2014.r.01

33. Ross RD, Cromwell GL, Stahly TS. Effects of source and particle size on the biological availability of calcium in calcium supplements for growing pigs. $J$ Anim Sci. (1984) 59:125-34. doi: 10.2527/jas1984.591125x

34. Merriman LA, Stein HH. Particle size of calcium carbonate does not affect apparent and standardized total tract digestibility of calcium, retention of calcium, or growth performance of growing pigs. J Anim Sci. (2016) 94:3844-50. doi: 10.2527/jas.2015-0252

35. Walk CL, Addo-Chidie EK, Bedford MR, Adeola O. Evaluation of a highly soluble calcium source and phytase in the diets of broiler chickens. Poultry Sci. (2012) 91:2255-63. doi: 10.3382/ps.2012-02224

36. Schlegel P, Gutzwiller A. Effect of dietary calcium level and source on mineral utilisation by piglets fed diets containing exogenous phytase. J Anim Physiol Anim Nutr. (2017) 101:e165-74. doi: 10.1111/jpn.12582

37. González-Vega JC, Walk CL, Stein HH. Effects of microbial phytase on apparent and standardized total tract digestibility of calcium in calcium supplements fed to growing pigs. J Anim Sci. (2015) 93:2255-64. doi: 10.2527/jas.2014-8215

38. González-Vega JC, Walk CL, Liu Y, Stein HH. The site of net absorption of $\mathrm{Ca}$ from the intestinal tract of growing pigs and effect of phytic acid, $\mathrm{Ca}$ level and Ca source on Ca digestibility. Arch Anim Nutr. (2014) 68:126-42. doi: 10.1080/1745039X.2014.892249

39. Garcia RA, Rosentrater KA, Flores RA. Characteristics of North American meat and bone meal relevant to the development of non-feed applications. Appl Eng Agric. (2006) 22:729-36. doi: 10.13031/2013.21989

40. Sulabo RC, Stein HH. Digestibility of phosphorus and calcium in meat and bone meal fed to growing pigs. J Anim Sci. (2013) 91:1285-94. doi: $10.2527 /$ jas.2011-4632

41. Perez JM, Bories G, Aumaitre A, Barrier-Guillot B, Delaveau A, Gueguen L, et al. Conséquences en élevage et pour le consommateur du remplacement des farines et des graisses animales. Prod Anim. (2002) 15:87-96. doi: 10.20870/productions-animales.2002.15.2.3689

42. Traylor SL, Cromwell GL, Lindemann MD. Bioavailability of phosphorus in meat and bone meal for swine. J Anim Sci. (2005) 83:1054-61. doi: $10.2527 / 2005.8351054 x$

43. Merriman LA, Walk CL, Stein HH. The effect of microbial phytase on the apparent and standardized total tract digestibility of calcium in feed ingredients of animal origin. J Anim Sci. (2016) 94(E-Suppl):110. doi: $10.2527 / \mathrm{msasas} 2016-240$ 
44. Jongbloed AW, Kemme PA. Apparent digestible phosphorus in the feeding of pigs in relation to availability, requirement and environment. 1. Digestible phosphorus in feedstuffs from plant and animal origin. Neth J Agric Sci. (1990). 38:567-575. doi: 10.18174/njas.v38i3B.16579

45. Van Harn J, Spek JW, Van Vuure CA, Van Krimpen MM. Determination of pre-cecal phosphorus digestibility of inorganic phosphates and bone meal products in broilers. Poultry Sci. (2017) 96:1334-40. doi: 10.3382/ps/pew458

46. Lee SA, Lagos LV, Stein HH. Digestible calcium and digestible phosphorus in swine diets. In: Smith JH, Eastwood L, editors. Proceedings of London Swine Clonference. (2019). p. 63-72.

47. NRC. Nutrient Requirements of Swine. Washington, DC: National Academies Press (1998).

48. Petersen GI, Pedersen C, Lindemann MD, Stein HH. Relative bioavailability of phosphorus in inorganic phosphorus sources fed to growing pigs. J Anim Sci. (2011) 89:460-6. doi: 10.2527/jas.2009-2161

49. She Y, Li D, Zhang S. Methodological aspects of determining phosphorus digestibility in swine: a review. Anim Nutr. (2017) 3:97-102. doi: 10.1016/j.aninu.2017.02.003

50. CVB Centraal Veevoederbureau. Veevoedertabel. Lelystad (2000).

51. Liu J, Bollinger DW, Ledoux DR, Veum TL. Effects of dietary calcium:phosphorus ratios on apparent absorption of calcium and phosphorus in the small intestine, cecum, and colon of pigs. J Anim Sci. (2000) 78:106-9. doi: 10.2527/2000.781106x

52. Bohlke RA, Thaler RC, Stein HH. Calcium, phosphorus, and amino acid digestibility in low-phytate corn, normal corn, and soybean meal by growing pigs. J Anim Sci. (2005) 83:2396-403. doi: 10.2527/2005.83102396x

53. Dilger RN, Adeola O. Estimation of true phosphorus digestibility and endogenous phosphorus loss in growing pigs fed conventional and low-phytate soybean meals. J Anim Sci. (2006) 84:627-34. doi: $10.2527 / 2006.843627 \mathrm{x}$

54. Stein HH, Fuller MF, Moughan PJ, Sève B, Mosenthin R, Jansman AJM, et al. Definition of apparent, true, and standardized ileal digestibility of amino acids in pigs. Livestock Sci. (2007) 109:282-5. doi: 10.1016/j.livsci.2007.01.019

55. Almeida FN, Stein H. Performance and phosphorus balance of pigs fed diets formulated on the basis of values for standardized total tract digestibility of phosphorus. J Anim Sci. (2010) 88:2968-77. doi: 10.2527/jas.2009-2285

56. Fan MZ, Sauer WC. Additivity of apparent ileal and fecal phosphorus digestibility values measured in single feed ingredients for growing-finishing pigs. Can J Anim Sci. (2002) 82:183-91. doi: 10.4141/A01-072

57. Fan MZ, Archbold T, Sauer WC, Lackeyram D, Rideout T, Gao Y, et al. Novel methodology allows simultaneous measurement of true phosphorus digestibility and the gastrointestinal endogenous phosphorus outputs in studies with pigs. J Nutr. (2001) 131:2388-96. doi: 10.1093/jn/131.9.2388

58. Petersen GI, Stein HH. Novel procedure for estimating endogenous losses and measurement of apparent and true digestibility of phosphorus by growing pigs. J Anim Sci. (2006) 84:2126-32. doi: 10.2527/jas.2005-479

59. González-Vega JC, Walk CL, Stein HH. Effect of phytate, microbial phytase, fiber, and soybean oil on calculated values for apparent and standardized total tract digestibility of calcium and apparent total tract digestibility of phosphorus in fish meal fed to growing pigs. J Anim Sci. (2015) 93:4808. doi: 10.2527/jas.2015-8992

60. Liu JB, Yan HL, Cao SC, Liu J, Zhang HF. Effect of feed intake level on the determination of apparent and standardized total tract digestibility of phosphorus for growing pigs. Anim Feed Sci Technol. (2018) 246:137-43. doi: 10.1016/j.anifeedsci.2018.10.012

61. Anwar MN, Ravindran V, Morel PCH, Ravindran G, Cowieson AJ. Measurement of true ileal calcium digestibility in meat and bone meal for broiler chickens using the direct method. Poultry Sci. (2016) 95:70-6. doi: $10.3382 / \mathrm{ps} / \mathrm{pev} 319$

62. Mutucumarana RK, Ravindran V. Measurement of true ileal phosphorus digestibility in meat and bone meal for broiler chickens using the direct method. Anim Feed Sci Technol. (2016) 219:249-56. doi: 10.1016/j.anifeedsci.2016.06.025

63. Merriman LA. Factors Affecting the Digestibility of Calcium in Feed Ingredients By Pigs. Univ. Illinois (2016).

64. Zhang F, Adeola O. Techniques for evaluating digestibility of energy, amino acids, phosphorus, and calcium in feed ingredients for pigs. Anim Nutr. (2017) 3:344-52. doi: 10.1016/j.aninu.2017.06.008
65. Bikker P, Blok MC. Phosphorus and Calcium Requirements of Growing Pigs and Sows. Technical Report (2017).

66. González-Vega JC, Walk CL, Liu Y, Stein HH. Determination of endogenous intestinal losses of calcium and true total tract digestibility of calcium in canola meal fed to growing pigs. J Anim Sci. (2013) 91:4807-16. doi: $10.2527 /$ jas.2013-6410

67. Liu JB, Cao SC, Chen L, Zhang HF. Effect of dietary phosphorus level on the determination of standardized and true total tract digestibility of phosphorus for growing pigs. Anim Feed Sci Technol. (2016) 215:117-23. doi: 10.1016/j.anifeedsci.2016.02.022

68. Stein HH, Adeola O, Cromwell GL, Kim SW, Mahan DC, Miller PS. Concentration of dietary calcium supplied by calcium carbonate does not affect the apparent total tract digestibility of calcium, but decreases digestibility of phosphorus by growing pigs. J Anim Sci. (2011) 89:2139-44. doi: 10.2527/jas.2010-3522

69. Younes H, Demigné C, Rémésy C. Acidic fermentation in the caecum increases absorption of calcium and magnesium in the large intestine of the rat. Br J Nutr. (1996) 75:301-14. doi: 10.1079/BJN19960132

70. Rodehutscord M. Determination of phosphorus availability in poultry. Worlds Poultry Sci J. (2013) 69:687-98. doi: 10.1017/S0043933913000688

71. Létourneau-Montminy MP, Narcy A, Lescoat P, Magnin M, Bernier JF, Sauvant $\mathrm{D}$, et al. Modeling the fate of dietary phosphorus in the digestive tract of growing pigs. J Anim Sci. (2011) 89:3596-611. doi: 10.2527/jas.2010-3397

72. Létourneau-Montminy MP, Jondreville C, Sauvant D, Narcy A. Metaanalysis of phosphorus utilization by growing pigs: effect of dietary phosphorus, calcium and exogenous phytase. Animal. (2012) 6:1590-600. doi: $10.1017 /$ S1751731112000560

73. Sauvant D, Schmidely P, Daudin JJ, St-Pierre NR. Meta-analyses of experimental data in animal nutrition. Animal. (2008) 2:1203-14. doi: $10.1017 /$ S1751731108002280

74. Sauvant D, Letourneau-Montminy MP, Schmidely P, Boval M, Loncke C, Daniel JB. Review: use and misuse of meta-analysis in animal science. Animal. (2020) 14:s207-22. doi: 10.1017/S1751731120001688

75. Jongbloed AW, Mroz Z, Kemme PA. The effect of supplementary Aspergillus niger phytase in diets for pigs on concentration and apparent digestibility of dry matter, total phosphorus, and phytic acid in different sections of the alimentary tract. J Anim Sci. (1992) 70:1159-68. doi: 10.2527/1992.70 41159x

76. Rapp C, Lantzsch HJ, Drochner W. Hydrolysis of phytic acid by intrinsic plant and supplemented microbial phytase (Aspergillus niger) in the stomach and small intestine of minipigs fitted with re-entrant cannulas. 3. Hydrolysis of phytic acid (IP6) occurrence of hydrolysis products (IP5, IP4, IP3 and IP2. J Anim Physiol Anim Nutr. (2001) 85:420-30. doi: 10.1046/j.1439-0396.2001.00337.x

77. Kemme PA, Schlemmer U, Mroz Z, Jongbloed AW. Monitoring the stepwise phytate degradation in the upper gastrointestinal tract of pigs. J Sci Food Agric. (2006) 86:612-22. doi: 10.1002/jsfa.2380

78. Adeola O, Olukosi OA, Jendza JA, Dilger RN, Bedford MR. Response of growing pigs to Peniophora lycii- and Escherichia coli-derived phytases or varying ratios of calcium to total phosphorus. Anim Sci. (2006) 82:637-44. doi: 10.1079/ASC200676

79. Létourneau-Montminy MP, Narcy A, Magnin M, Sauvant D, Bernier JF, Pomar C, et al. Effect of reduced dietary calcium concentration and phytase supplementation on calcium and phosphorus utilization in weanling pigs with modified mineral status. J Anim Sci. (2010) 88:1706-17. doi: $10.2527 /$ jas.2008-1615

80. NRC. Nutrient Requirements of Poultry: Ninth Revised Edition. Washington, DC: National Academies Press (1994).

81. FAO, WHO. Human Vitamin and Mineral Requirements. Human Vitamin and Mineral Requirements (2001).p. 303.

82. Baker DH. Problems and pitfalls in animal experiments designed to establish dietary requirements for essential nutrients. J Nutr. (1986) 116:2339-49. doi: 10.1093/jn/116.12.2339

83. Sauveur B, Perez JM. Alimentation minérale des animaux monogastriques. In: L'alimentation des Animaux Monogastriques: porc, lapin, volailles. $2 \mathrm{e}$ ed. Paris: INRA. (1989). p. 23-31.

84. Jondreville C, Dourmad JY. Phosphorus in pig nutrition. Prod Anim. (2006) 18:183-92. doi: 10.20870/productions-animales.2005.18.3.3523 
85. Guéguen L, Perez JM. A re-evaluation of recommended dietary allowances of calcium and phosphorus for pigs. Proc Nutr Soc. (1981) 40:273-8. doi: 10.1079/PNS19810043

86. Jongbloed AW, Everts H, Kemme PA, Mroz Z. Quantification of absorbability and requirements of macroelements. In: Kyriazakis I, editor. Quantitative Biology of the pig. Wallingford, UK: CAB International (1999). p. 275-98.

87. Gauthier R, Largouët C, Gaillard C, Cloutier L, Guay F, Dourmad JY. Dynamic modeling of nutrient use and individual requirements of lactating sows. J Anim Sci. (2019) 97:2822-36. doi: 10.1093/jas/skz167

88. Gaillard C, Gauthier R, Cloutier L, Dourmad JY. Exploration of individual variability to better predict the nutrient requirements of gestating sows. $J$ Anim Sci. (2019) 97:4934-45. doi: 10.1093/jas/skz320

89. Couture C, Chiasson R, Pomar C, Letourneau MP. Évolution de la teneur en protéine corporelle et du contenu minéral osseux des porcs charcutiers nourris avec différents niveaux de phosphore et calcium alimentaires. J Rech Porcine. (2018) 50:167-8.

90. Sauvant D, Grizard J. Bases d'un modèle décrivant la régulation du métabolisme du glucose de la chèvre en lactation. Listing. (1992) 41:115-6. doi: 10.1051/rnd:19920164

91. van Milgen J, Valancogne A, Dubois S, Dourmad JY, Sève B, Noblet J. InraPorc: a model and decision support tool for the nutrition of growing pigs. Anim Feed Sci Technol. (2008) 143:387-405. doi: 10.1016/j.anifeedsci.2007.05.020

92. Lautrou M, Létourneau-Montminy MP, Schmidely P, Pomar C. Anatomical and chemical composition of growing pigs at different bodyweights. Banff Pork Seminar. (2021).

93. Alexander LS, Qu A, Cutler SA, Mahajan A, Lonergan SM, Rothschild $\mathrm{MF}$, et al. Response to dietary phosphorus deficiency is affected by genetic background in growing pigs. J Anim Sci. (2008) 86:2585-95. doi: 10.2527/jas.2007-0692

94. Cloutier L, Pomar C, Létourneau Montminy MP, Bernier JF, Pomar J. Evaluation of a method estimating real-time individual lysine requirements in two lines of growing-finishing pigs. Animal. (2015) 9:561-8. doi: 10.1017/S1751731114003073

95. Dersjant-Li Y, Awati A, Schulze H, Partridge G. Phytase in nonruminant animal nutrition: a critical review on phytase activities in the gastrointestinal tract and influencing factors. J Sci Food Agric. (2015) 95:878-96. doi: 10.1002/jsfa.6998

96. Greiner R, Konietzny U. Phytase for food application. Food Technol Biotechnol. (2006) 44:125-140.

97. Dersjant-Li Y, Hruby M, Evans C, Greiner R. A critical review of methods used to determine phosphorus and digestible amino acid matrices when using phytase in poultry and pig diets. J Appl Anim Nutr. (2019) 7:e2. doi: 10.1017/JAN.2019.1

98. Lei XG, Weaver JD, Mullaney E, Ullah AH, Azain MJ. Phytase, a new life for an "old" enzyme. Ann Rev Anim Biosci. (2013) 1:283-309. doi: 10.1146/annurev-animal-031412-103717

99. Augspurger NR, Webel DM, Lei XG, Baker DH. Efficacy of an E. coli phytase expressed in yeast for releasing phytate-bound phosphorus in young chicks and pigs. J Anim Sci. (2003) 81:474-83. doi: 10.2527/2003.812474x

100. Vasudevan UM, Krishna S, Jalaja V, Pandey A. Microbial phytase: impact of advances in genetic engineering in revolutionizing its properties and applications. Bioresource Technol. (2017) 245:1790-9. doi: 10.1016/j.biortech.2017.05.060

101. van Dijck PWM, Selten GCM, Hempenius RA. On the safety of a new generation of DSM Aspergillus niger enzyme production strains. Regul Toxicol Pharmacol. (2003) 38:27-35. doi: 10.1016/S0273-2300(03)00049-7

102. Maenz DD, Engele-Schaan CM, Newkirk RW, Classen HL. The effect of minerals and mineral chelators on the formation of phytase-resistant and phytase-susceptible forms of phytic acid in solution and in a slurry of canola meal. Anim Feed Sci Technol. (1999) 81:177-92. doi: 10.1016/S0377-8401(99)00085-1

103. Adeola O, Cowieson AJ. BOARD-INVITED REVIEW: Opportunities and challenges in using exogenous enzymes to improve nonruminant animal production. J Anim Sci. (2011) 89:3189-218. doi: 10.2527/jas.2010-3715

104. Lei XG, Porres JM. Phytase enzymology, applications, and biotechnology. Biotechnol Lett. (2003) 25:1787-94. doi: 10.1023/A:1026224101580
105. Menezes-Blackburn D, Gabler S, Greiner R. Performance of seven commercial phytases in an in vitro simulation of poultry digestive tract. $J$ Agric Food Chem. (2015) 63:6142-9. doi: 10.1021/acs.jafc.5b01996

106. Morales GA, Moyano FJ, Marquez L. In vitro assessment of the effects of phytate and phytase on nitrogen and phosphorus bioaccessibility within fish digestive tract. Anim Feed Sci Technol. (2011) 170:209-21. doi: 10.1016/j.anifeedsci.2011.08.011

107. Christensen T, Mejldal R, Dersjant-li Y, Debicki-Garnier AM, Messager B. Activité phytasique relative dans une gamme de $\mathrm{pH}$ allant résultats $\mathrm{d}$ ' une étude in vitro comparant trois phytases. J Rech Porcine. (2019) 51:1134.

108. De Jong JA, Woodworth JC, DeRouchey JM, Goodband RD, Tokach MD, Dritz SS, et al. Stability of four commercial phytase products under increasing thermal conditioning temperatures. Transl Anim Sci. (2017) 1:255-60. doi: 10.2527/tas2017.0030

109. Eeckhout W, De Paepe M. Total phosphorus, phytate-phosphorus and phytase activity in plant feedstuffs. Anim Feed Sci Technol. (1994) 47:19-29. doi: 10.1016/0377-8401(94)90156-2

110. Kornegay ET. Digestion of phosphorus and other nutrients: the role of phytases and factors influencing their activity. In: Bedford MR, Partridge GG, editors. Enzymes in Farm Animal Nutrition. Wallingford, UK: CABI Publishing (2001).

111. Garrett JB, Kretz KA, O’Donoghue E, Kerovuo J, Kim W, Barton NR, et al. Enhancing the thermal tolerance and gastric performance of a microbial phytase for use as a phosphate-mobilizing monogastricfeed supplement. Appl Environ Microbiol. (2004) 70:3041-6. doi: 10.1128/AEM.70.5.3041-3046.2004

112. Outchkourov N, Petkov S. Phytases for feed applications. In: Vogel A, May O, editors. Industrial Enzyme Applications. Weinheim: Wiley-VCH (2013). p. $255-86$.

113. Champagne ET, Fisher MS. Binding differences of $\mathrm{Zn}(\mathrm{II})$ and $\mathrm{Cu}(\mathrm{II})$ ions with phytate. J Inorg Biochem. (1990) 38:217-23. doi: 10.1016/0162-0134(90)84014-G

114. Blavi L, Sola-Oriol D, Perez JF, Stein HH. Effects of zinc oxide and microbial phytase on digestibility of calcium and phosphorus in maize-based diets fed to growing pigs. J Anim Sci. (2017) 95:847-54. doi: 10.2527/jas2016.1149

115. Augspurger NR, Spencer JD, Webel DM, Baker DH. Pharmacological zinc levels reduce the phosphorus-releasing efficacy of phytase in young pigs and chickens. J Anim Sci. (2004) 82:1732-9. doi: 10.2527/2004.8261732x

116. Pang Y, Applegate TJ. Effects of copper source and concentration on in vitro phytate phosphorus hydrolysis by phytase. J Agric Food Chem. (2006) 54:1792-6. doi: 10.1021/jf052053b

117. Ren $\mathrm{P}$, Chen J, Wedekind $\mathrm{K}$, Hancock $\mathrm{D}$, Vázquez-A nón M. Interactive effects of zinc and copper sources and phytase on growth performance, mineral digestibility, bone mineral concentrations, oxidative status, and gut morphology in nursery pigs. Transl Anim Sci. (2020) 4:783-98. doi: 10.1093/tas/txaa083

118. Ren P, Chen J, Hancock D, Vazquez-A nón M. Interactive effects of copper sources and a high level of phytase in phosphorus-deficient diets on growth performance, nutrient digestibility, tissue mineral concentrations, and plasma parameters in nursery pigs. Biol Trace Elem Res. (2021) 199:4582-92. doi: 10.1007/s12011-021-02580-x

119. Richards JD, Zhao J, Harrell RJ, Atwell CA, Dibner JJ. Trace mineral nutrition in poultry and swine. Asian Aust J Anim Sci. (2010) 23:1527-34. doi: 10.5713/ajas.2010.r.07

120. Cheryan M, Rackis JJ. Phytic acid interactions in food systems. Crit Rev Food Sci Nutr. (1980) 13:297-335. doi: 10.1080/10408398009527293

121. Cowieson AJ, Wilcock P, Bedford MR. Super-dosing effects of phytase in poultry and other monogastrics. Worlds Poultry Sci J. (2011) 67:225-35. doi: $10.1017 /$ S0043933911000250

122. Walk CL. The influence of calcium on phytase efficacy in non-ruminant animals. Anim Prod Sci. (2016) 56:1345. doi: 10.1071/AN15341

123. Lei XG, Ku PK, Miller ER, Yokoyama MT, Ullrey DE. Calcium level affects the efficacy of supplemental microbial phytase in corn-soybean meal diets of weanling pigs1. J Anim Sci. (1994) 72:139-43. doi: 10.2527/1994.721139x

124. Qian H, Kornegay ET, Conner DEJ. Adverse effects of wide calcium:phosphorus ratios on supplemental phytase efficacy for weanling pigs fed two dietary phosphorus levels. J Anim Sci. (1996) 74:1288-97. doi: $10.2527 / 1996.7461288 x$ 
125. Liu J, Bollinger DW, Ledoux DR, Veum TL. Lowering the dietary calcium to total phosphorus ratio increases phosphorus utiliza- tion in low-phosphorus corn-soybean meal diets supplemented with microbial phytase for growingfinishing pigs. J Anim Sci. (1998) 76:808-13. doi: 10.2527/1998.763808x

126. Driver JP, Pesti GM, Bakalli RI, Edwards HM. Effects of calcium and nonphytate phosphorus concentrations on phytase efficacy in broiler chicks. Poultry Sci. (2005) 84:1406-17. doi: 10.1093/ps/84.9.1406

127. Wu F, Tokach MD, Dritz SS, Woodworth JC, Derouchey JM, Goodband RD, et al. Effects of dietary calcium to phosphorus ratio and addition of phytase on growth performance of nursery pigs. J Anim Sci. (2018) 96:1825-37. doi: $10.1093 /$ jas/sky101

128. Underwood EJ, Mertz W. Introduction. In: Trace Elements in Human and Animal Nutrition. 5th rev. ed. New York, NY: Academic Press (1987). p. 1-19.

129. Stauffer M, Baylink D, Wergedal J, Rich C. Bone repletion in calcium deficient rats fed a high calcium diet. Calcif Tissue Res. (1972) 9:163-72. doi: 10.1007/BF02061954

130. Stauffer M, Baylink D, Wergedal J, Rich C. Decreased enhanced bone formation, mineralization, and enhanced resorption and in calcium-deficient rats. Am J Physiol. (1973) 225:163-72. doi: 10.1152/ajplegacy.1973.225.2.269

131. Drivdahl RH, Liu CC, Baylink DJ. Regulation of bone repletion in rats subjected to varying low-calcium stress. Am J Physiol. (1984) 246:R190-6. doi: 10.1152/ajpregu.1984.246.2.R190

132. Åkesson K, Lau KHW, Johnston P, Imperio E, Baylink DJ. Effects of shortterm calcium depletion and repletion on biochemical markers of bone turnover in young adult women. J Clin Endocrinol Metab. (1998) 83:1921-7. doi: 10.1210/jc.83.6.1921

133. Goff JP. Macromineral physiology and application to the feeding of the dairy cow for prevention of milk fever and other periparturient mineral disorders. Anim Feed Sci Technol. (2006) 126:237-57. doi: 10.1016/j.anifeedsci.2005.08.005

134. Friggens NC, Andersen JB, Larsen T, Aaes O, Dewhurst RJ. Priming the dairy cow for lactation: a review of dry cow feeding strategies. Anim Res. (2004) 53:453-73. doi: 10.1051/animres:2004037

135. Kasper C, Schlegel P, Ruiz-Ascacibar I, Stoll P, Bee G. Accuracy of predicting chemical body composition of growing pigs using dual-energy X-ray absorptiometry. bioRxiv. (2020). 1-24. doi: 10.1101/2020.09.15.286153

136. Gonzalo E, Létourneau-Montminy MP, Narcy A, Bernier JF, Pomar C. Consequences of dietary calcium and phosphorus depletion and repletion feeding sequences on growth performance and body composition of growing pigs. Animal. (2018) 12:1165-73. doi: 10.1017/S1751731117002567

137. Yan F, Angel R, Ashwell C, Mitchell A, Christman M. Evaluation of the broiler's ability to adapt to an early moderate deficiency of phosphorus and calcium. Poultry Sci. (2005) 84:1232-41. doi: 10.1093/ps/84.8.1232

138. Ashwell CM, Angel R. Nutritional genomics: a practical approach by early life conditioning with dietary phosphorus. Rev Brasileira de Zootecnia. (2010) 39(Suppl. spe):268-78. doi: 10.1590/S1516-35982010001300030

139. Rousseau X, Valable AS, L'Etourneau-Montminy MP, Meme N, Godet E, Magnin M, et al. Metabolism and nutrition: adaptive response of broilers to dietary phosphorus and calcium restrictions. Poultry Sci. (2016) 95:2849-60. doi: $10.3382 /$ ps/pew 172

140. Valable AS, Narcy A, Duclos MJ, Pomar C, Page G, Nasir Z, et al. Effects of dietary calcium and phosphorus deficiency and subsequent recovery on broiler chicken growth performance and bone characteristics. Animal. (2018) 12:1555-63. doi: 10.1017/S1751731117003093

141. Valable AS, Létourneau-Montminy MP, Klein S, Lardic L, Lecompte F, Metayer-Coustard S, et al. Early-life conditioning strategies to reduce dietary phosphorus in broilers: underlying mechanisms. J Nutr Sci. (2020) 9:e28. doi: $10.1017 /$ jns. 2020.17
142. Ryan WF, Lynch PB, O'Doherty JV. Compensatory effect of dietary phosphorus on performance of growing pigs and development of bone mineral density assessed using dual energy X-ray absorptiometry. Livestock Sci. (2011) 138:89-95. doi: 10.1016/j.livsci.2010.12.006

143. Lautrou M, Pomar C, Schmidely P, Laval U, Mosar UMR, Paris-saclay $\mathrm{U}$, et al. Effets d'une déplétion-réplétion en phosphore et calcium sur les performances et la minéralisation osseuse des porcs en croissance. $J$ Rech Porcine. (2021) 53:163-8.

144. Nussey SS, Whitehead SA. Endocrinology, An Integrated Approach. Oxford, U.K: BIOS Scientific (2001).

145. Gonzalo E. Consequences of a dietary phosphorus and calcium depletion and repletion strategy in growing-finishing pigs (Ph.D. thesis) (2017).

146. Schanler RJ, Abrams SA, Sheng HP. Calcium and phosphorus deficiencies affect mineral distribution in neonatal miniature piglets. Am J Clin Nutr. (1991) 54:420-4. doi: 10.1093/ajcn/54.2.420

147. Mitchell AD, Scholz AM, Pursel VG. Total body and regional measurements of bone mineral content and bone mineral density in pigs by dual energy X-ray absorptiometry. J Anim Sci. (2001) 79:2594-2604. doi: $10.2527 / 2001.79102594 x$

148. Schröder B, Schlumbohm C, Kaune R, Breves G. Role of calbindin-D9k in buffering cytosolic free $\mathrm{Ca} 2+$ ions in pig duodenal enterocytes. J Physiol. (1996) 492:715-22. doi: 10.1113/jphysiol.1996.sp021340

149. Allen MJ. Biochemical markers of bone metabolism in animals: uses and limitations. Vet Clin Pathol. (2003) 32:101-13. doi: 10.1111/j.1939-165X.2003.tb00323.x

150. Lagos LV, Lee SA, Bedford MR, Stein HH. Formulation of diets for pigs based on a ratio between digestible calcium and digestible phosphorus results in reduced excretion of calcium in urine without affecting retention of calcium and phosphorus compared with formulation based on values for total. J Anim Sci. (2021) 99:1-7. doi: 10.1093/jas/skab138

151. Pomar C, Hauschild L, Zhang GH, Pomar J, Lovatto PA. Applying precision feeding techniques in growing-finishing pig operations. Rev Brasileira de Zoot. (2009) 38:226-37. doi: 10.1590/S1516-35982009001300023

152. Andretta I, Pomar C, Rivest J, Pomar J, Lovatto PA, Radünz Neto J. The impact of feeding growing-finishing pigs with daily tailored diets using precision feeding techniques on animal performance, nutrient utilization, and body and carcass composition1. J Anim Sci. (2014) 92:3925-36. doi: $10.2527 /$ jas.2014-7643

Conflict of Interest: The authors declare that the research was conducted in the absence of any commercial or financial relationships that could be construed as a potential conflict of interest.

Publisher's Note: All claims expressed in this article are solely those of the authors and do not necessarily represent those of their affiliated organizations, or those of the publisher, the editors and the reviewers. Any product that may be evaluated in this article, or claim that may be made by its manufacturer, is not guaranteed or endorsed by the publisher.

Copyright (c) 2021 Lautrou, Narcy, Dourmad, Pomar, Schmidely and Létourneau Montminy. This is an open-access article distributed under the terms of the Creative Commons Attribution License (CC BY). The use, distribution or reproduction in other forums is permitted, provided the original author(s) and the copyright owner(s) are credited and that the original publication in this journal is cited, in accordance with accepted academic practice. No use, distribution or reproduction is permitted which does not comply with these terms. 